\title{
Bovine respiratory disease in Brasil: a short review ${ }^{1}$
}

\section{Doença respiratória bovina no Brasil: uma breve revisão}

\author{
Mariana Motta de Castro; Thalita Evani Silva de Oliveira3; Selwyn Arlington Headley*
}

\section{Highlights}

There are few descriptions of BRD in Brazil relative to North American and Australia. Immunohistochemistry can be used for the in-situ diagnosis of pathogens of BRD. OvHV-2 and HoBi-like pestivirus should be associated with the development of BRD. A diagnosis of BRD requires efficient clinical history and good laboratory analyses. There are pulmonary patterns for specific infectious agents of BRD.

\begin{abstract}
The bovine respiratory disease (BRD) complex is a multifactorial and multietiological disease entity described in all geographic regions of Brazil. This brief review discusses aspects related to epidemiology, etiologic agents, clinical and pathological manifestations, and challenges in the diagnosis of BRD in Brazil. The main infectious disease agents associated with respiratory outbreaks in cattle from Brazil are bovine alphaherpesvirus type 1, bovine viral diarrhea virus, bovine respiratory syncytial virus, and Mycoplasma bovis. Ovine gammaherpesvirus-2 and HoBi-like pestivirus have been associated with the development of pneumonia in adult cattle and calves, respectively in Brazil, and should be considered as possible causes of BRD. Additionally, studies using epidemiological data, histopathological and molecular associations with morbidity and mortality should be carried out in Brazil, to demonstrate the real impacts of BRD on livestock. Key words: Epidemiology. Cattle disease. Diagnosis. Respiratory pathogens.
\end{abstract}

\section{Resumo}

O complexo da doença respiratória bovina (DRB) é uma enfermidade multifatorial e multietiológica descrita em todas as regiões geográficas do Brasil. Essa breve revisão discute os aspectos relacionados epidemiologia, aos agentes etiológicos, as manifestações clínicas e patológicas e os desafios no diagnóstico da DRB no Brasil. Os principais agentes associados a surtos respiratórios brasileiros são: alfaherpesvírus bovino tipo 1, vírus da diarreia viral bovina, vírus sincicial respiratório bovino e Mycoplasma bovis. Gammaherpesvirusovino tipo-2 e HoBi-like pestivírus foram associados ao desenvolvimento de pneumonia em bovinos

1 Part of the PhD thesis of MMC and TESO.

2 Doctorate Student, Graduate Program in Animal Bioscience, Universidade de Cuiabá, UNIC, Cuiabá, MT, Brazil. E-mail: mottavet@hotmail.com

${ }^{3}$ Doctorate Student, Graduate Program in Animal Health Science, Universidade Estadual de Londrina, UEL, Londrina, PR, Brazil. E-mail: thalitamvet@uel.br

${ }^{4}$ Prof. Dr. Laboratory of Animal Pathology, UEL, Londrina, PR, Brazil. Professor of Veterinary Pathology, Graduate Programs in Animal Health Science, UEL, and Animal Bioscience, UNIC. E-mail: selwyn.headley@uel.br

* Author for correspondence

Received: July 072020 - Approved: Mar. 18, 2021 
adultos e bezerros no país, respectivamente, e devem ser considerados como possíveis agentes no desenvolvimento da DRB. Adicionalmente, mais estudos utilizando dados epidemiológicos, associação histopatológica e molecular com morbidade e mortalidade devam ser realizados no Brasil, para demonstrar os verdadeiros efeitos de DRB em bovinos confinados.

Palavras-chave: Epidemiologia. Diagnóstico. Doença bovina. Patógenos respiratórios.

\section{Introduction}

The bovine respiratory disease (BRD) complex is a consequence of the interaction of multiple factors related mainly to host immunity, the pathogenicity of respiratory microorganisms, and environmental characteristics that alter the probability of exposure to pathogens (Fulton, 2009). BRD occurs in beef and dairy cattle, and it has been suggested that cattle reared in feedlots or semi-confined conditions can increase the occurrence and mortality related to this disease (Baptista, Rezende, Fonseca, Nogueira, \& Headley, 2017). Additionally, BRD can be considered as a syndrome caused by the interaction of several viral and bacterial infections that result in clinical and pulmonary alterations (Fulton, 2009; Gershwin, Van Eenennaam, Anderson, McEligot, \& Shao, 2015) with a high economic loss to the farmer (Baptista et al., 2017).

The clinical signs manifested in cattle with BRD may be non-specific, which often impede the clinical diagnosis (Cooper \& Brodersen, 2010) some signs frequently encountered include dyspnea, tachypnea, cough, nasal and ocular discharge, depression, anorexia, fever, and pulmonary rales (Fulton, 2009; Griffin, Chengappa, Kuszak, \& McVey, 2010; Timsit, Hallewell, Booker, Tison, \& Amat, 2017). Since BRD is a syndrome that has multiple signs and is associated with several infectious disease agents; the specific pathogens involved in individual cases or outbreaks are often undiagnosed. Consequently, assessment of the animal response and risk factors associated with each pathogen can result in a better understanding of this disease (Grissett, White, \& Larson, 2015).

This brief review discusses the data of the respiratory disease complex in cattle from Brazil, considering the epidemiological data, the infectious agents, and the clinical and pathological manifestations associated with its development, based on studies published in scientific journals. Additionally, this review has a great significance in terms of its timing, since currently no study was focused on the collective evaluation of the manifestations and agents related to BRD in Brazil.

\section{Epidemiological data}

$B R D$ is a frequent disease that causes mortality in calves (Brazil et al., 2013; USDA, 2017; Dubrovsky et al., 2019), and dairy cattle (Francoz et al., 2015; Richter et al, 2017; Yarnall \& Thrusfield, 2017), and is the leading cause of losses in feedlot cattle (Fulton et al., 2009; Hay et al., 2016; Baptista et al., 2017), resulting in substantial losses to livestock (BlakebroughHall et al., 2020).

Comprehensive clinical-epidemiological data collected to assess the prevalence and degree of losses induced by the BRD complex are still scarce in Brazil (Oliveira, Pelaquim, et 
al., 2020), especially when compared to data from North America (Loneragan, Dargatz, Morley, \& Smith, 2001; Gagea, Bateman, van Dreumel, McEwen, \& Carman, 2006; Hessman, Fulton, Sjeklocha, Murphy, \& Ridpath, 2009; Taylor, Fulton, Lehenbauer, Step, \& Confer, 2010) and Australia (Moore, O'Dea, Perkins, \&
O'Hara, 2015; Hay et al., 2016; Schibrowski, Gibson, Hay, Mahony, \& Barnes, 2018). Published data show that most studies done in Brazil regarding BRD were conducted in the southern and southeastern regions of the country (Table 1).

Table 1

Microorganisms frequently associated with bovine respiratory disease in Brazil

\begin{tabular}{|c|c|c|}
\hline $\begin{array}{l}\text { Pathogenic } \\
\text { respiratory agents }\end{array}$ & $\begin{array}{l}\text { Geographical } \\
\text { region }\end{array}$ & References \\
\hline $\begin{array}{l}\text { Bovine } \\
\text { alphaherpesvirus-1, } \\
\text { BoHV-1 }\end{array}$ & $\begin{array}{l}\text { Paraná } \\
\text { São Paulo }\end{array}$ & $\begin{array}{l}\text { (Dias, Médici, Alexandrino, Medeiros, \& Alfier, 2010; Headley, } \\
\text { Alfieri, Oliveira, Beuttemmuller, \& Alfieri, 2014; Hoppe, Souza- } \\
\text { Pollo, Medeiros, Samara, \& Carvalho, 2019; Oliveira, Pelaquim, } \\
\text { et al., 2020) }\end{array}$ \\
\hline $\begin{array}{l}\text { Bovine coronavirus, } \\
\text { BCoV }\end{array}$ & $\begin{array}{l}\text { Paraná } \\
\text { São Paulo }\end{array}$ & $\begin{array}{l}\text { (Beuttemmuller, Alfieri, Headley, \& Alfieri, 2017; Oliveira, Dall } \\
\text { Agnol, et al., 2020) }\end{array}$ \\
\hline $\begin{array}{l}\text { Bovine } \\
\text { parainfluenza } \\
\text { virus-3, BPIV-3 }\end{array}$ & $\begin{array}{l}\text { Paraná } \\
\text { Rio Grande do Sul } \\
\text { São Paulo }\end{array}$ & $\begin{array}{l}\text { (Cole, 1971; Gonçalves, Spilki, Chiminazzo, Oliveira, \& Franco, } \\
\text { 2003; Vaucher, Dezen, Simonetti, Spilki, \& Roehe, 2011; } \\
\text { Oliveira, \& Pelaquim, et al. ,2020; Oliveira, Dall Agnol, et al., } \\
\text { 2020) }\end{array}$ \\
\hline $\begin{array}{l}\text { Bovine respiratory } \\
\text { syncytial virus, } \\
\text { BRSV }\end{array}$ & $\begin{array}{l}\text { Alagoas } \\
\text { Paraná } \\
\text { Rio Grande do Sul } \\
\text { São Paulo }\end{array}$ & $\begin{array}{l}\text { (Gonçalves, Simanke, Jost, Hôtzel, \& Soglio, 1993; Driemeier, } \\
\text { Gomes, Moojen, Arns, \& Vogg, 1997; Flores, Weiblen, Medeiros, } \\
\text { Botton, \& Irigoyen, 2000; Oliveira, Pelaquim, et al., 2020; } \\
\text { Oliveira, Dall Agnol, et al., 2020) }\end{array}$ \\
\hline $\begin{array}{l}\text { Bovine viral } \\
\text { diarrhea virus, } \\
\text { BVDV }\end{array}$ & $\begin{array}{l}\text { Rio Grande do Sul } \\
\text { Paraná }\end{array}$ & $\begin{array}{l}\text { (Flores, Weiblen, Vogel, Roehe, \& Alfieri, 2005; Hoppe et al., } \\
\text { 2019; Oliveira, Pelaquim, et al., 2020; Oliveira, Dall Agnol, et al., } \\
\text { 2020) }\end{array}$ \\
\hline Histophilus somni & $\begin{array}{l}\text { Minas Gerais } \\
\text { Paraná }\end{array}$ & $\begin{array}{l}\text { (Headley, Oliveira, Figueira, Bronkhorst, \& Alfieri, 2013; Headley } \\
\text { et al., 2014; Headley, Balbo, Alfieri, Saut, \& Baptista, 2017; } \\
\text { Oliveira, Dall Agnol, et al., 2020) }\end{array}$ \\
\hline $\begin{array}{l}\text { Mannheimia } \\
\text { haemolytica }\end{array}$ & $\begin{array}{l}\text { Minas Gerais } \\
\text { Paraná } \\
\text { São Paulo }\end{array}$ & $\begin{array}{l}\text { (Coutinho, Oliveira, Silva, Oliveira, \& Marcondes, 2009; Baptista } \\
\text { et al., 2017; Magalhães, Baptista, Fonseca, Menezes, Nogueira, } \\
\text { 2017) }\end{array}$ \\
\hline Mycoplasma bovis & $\begin{array}{l}\text { Bahia } \\
\text { Minas Gerais } \\
\text { Paraná } \\
\text { São Paulo }\end{array}$ & $\begin{array}{l}\text { (Pretto, Müller, Freitas, Mettifogo, \&, Buzinhanr, 2001; Marques, } \\
\text { Buzinhani, Oliveira, Yamaguti, \& Ferreira, 2007; Tortorelli, Carrillo } \\
\text { Gaeta, Mendonça Ribeiro, Miranda Marques, \& Timenetsky, } \\
\text { 2017; Gaeta, Ribeiro, Alemán, Yoshihara, \& Nassar, 2018; } \\
\text { Oliveira and Pelaquim, et al., 2020; Oliveira, \& Dall Agnol, et al., } \\
\text { 2020) }\end{array}$ \\
\hline $\begin{array}{l}\text { Pasteurella } \\
\text { multocida }\end{array}$ & $\begin{array}{l}\text { Minas Gerais } \\
\text { Paraná } \\
\text { São Paulo }\end{array}$ & (Coutinho et al., 2009; Baptista et al., 2017) \\
\hline
\end{tabular}


In a 12-year retrospective study (Brasil et al., 2013) done in Rio Grande do Sul with 306 cattle, respiratory infections were responsible for $15 \%$ of 33 calves necropsied (Brasil et al., 2013). Age ranged from 2 days to 12 months, with calves up to 3 months old (51.5\%; 17/33) being the most affected (Brasil et al., 2013). In Brazil, statistical data collected over a period of two years from beef cattle feedlots revealed morbidity caused by BRD as $6.13 \%$ $(11,577 / 188,862)$ and mortality as $0.21 \%$ (397/188,862) (Baptista et al., 2017).

The impact of BRD can be estimated by the sum of direct costs, which include mortality, morbidity, reduced animal performance and carcass quality, and indirect labor and infrastructure costs (Jim, 2009). The economic loss caused by morbidity and mortality linked to the BRD complex is extensive and is mainly related to the costs of treating and preventing the disease (Apley, 2006; Griffin et al., 2010; Timsit et al., 2017).

In Brazil, the expenses due to mortality and morbidity associated with BRD were estimated atUS\$14,334.00 and US\$16,315.40 for every 10,000 cattle, respectively (Baptista et al., 2017). Additionally, it was estimated that the economic effects due to morbidity associated with BRD in Brazil were US\$ 6.31 million/year, while mortality losses were US\$ 5.54 million, totaling an annual loss of US\$ 11.85 million (Baptista et al., 2017).

Data from a feedlot in the state of Goiás revealed that BRD was the biggest health problem encountered, accounting for $46.7 \%$ of all herd diseases (Malafaia, Granato, Costa, Souza, \& Costa, 2016). Additionally, these authors indicated that treatment costs were high on average, from $7 \%$ to $15 \%$ of live weight to be gained during the finishing period of the traditional system.
Australian researchers evaluated the economic effects of BRD and observed morbidity rates of $18 \%$ and mortality of $2.1 \%$, with an average net loss of Australian dollar (AUD \$) 1,647.53 (US\$ 1,1738) per mortality (Blakebrough-Hall et al., 2020). This study demonstrated that cattle that were treated three times or more for BRD had lighter carcasses averaging $39.6 \mathrm{~kg}$ and yielded revenue of around AUD \$ 384.9 (US\$ 274.2) less compared to untreated cattle. Additionally, the carcass yield of cattle with severe lung disease at slaughter was $0.3 \mathrm{~kg} /$ day less, being on average $14.3 \mathrm{~kg}$ lighter at slaughter, generating a loss of AUD $\$ 91.50$ (US\$ 65.2) compared to that of cattle without pulmonary disease (Blakebrough-Hall et al., 2020). Animals with subclinical (16 kg) and clinical $(24.1 \mathrm{~kg})$ BRD had lighter carcasses, and the revenue collected at slaughter was reduced by AUD \$ 67.10 (\$ 47.8) and AUD \$ 213.90 (\$152.3), respectively, when compared with healthy animals that were never treated and without pulmonary disease (BlakebroughHall et al., 2020).

Etiological agents associated with the development of BRD in Brazil

The most frequent viral agents of BRD include bovine alphaherpesvirus type 1, BoHV1 (Warren, Babiuk, \& Campos, 1996; Muylkens, Thiry, Kirten, Schynts, \& Thiry, 2007; Risalde, Molina, Sonchez-Cordon, Pedrera, \& RomeroPalomo, 2013), bovine viral diarrhea virus, BVDV (Fulton, Purdy, Confer, Saliki, \& Loan. 2000; Gagea et al., 2006), bovine parainfluenza virus type 3, BPIV-3 (Fulton, Briggs, Payton, Confer, \& Saliki, 2004; Ceribasi, Ozkaraca, Ceribasi, \& Ozer, 2014), bovine respiratory syncytial virus, BRSV (Fulton et al., 2000; Gagea 
et al., 2006) and bovine coronavirus, BCoV (Gagea et al., 2006; Fulton, Step, Wahrmund, Burge, \& Payton, 2011). Most viral agents of cattle induce immunosuppression resulting in secondary or concomitant infections (Fulton, 2009; Caswell \& Williams, 2016). HoBilike pestivirus, an emerging agent initially identified in Europe in fetal bovine serum imported from Brazil, was related to respiratory manifestations, inducing viremia, leukopenia, fever, and nasal secretions (Bauermann, Ridpath, Weiblen, \& Flores, 2013). Additionally, HoBi-like pestivirus was associated with the development of pneumonia in a calf from Italy (Decaro, Mari, Pinto, Lucente, \& Sciarretta, 2012) and in several calves from an outbreak of BRD in São Paulo (Hoppe et al., 2019).

Other agents of viral origin not frequently associated with BRD are influenza $D$ virus (IDV) and bovine adenovirus type 3 (BAV3). Serological studies demonstrated that IDV has a wide geographic distribution with high seroprevalence in many herds and has been circulated in the USA since 2003 (Ferguson, Eckard, Epperson, Long, \& Smith, 2015; Luo, Ferguson, Smith, Woolums, \& Epperson, 2017). This virus was also identified in the United Kingdom (Dane, Duffy, Guelbenzu, Hause, \& Fee, 2019) and Mexico (Mitra, Cernicchiaro, Torres, Li, \& Hause, 2016). BAV3 was first associated with the BRD complex in experimental studies in calves from Canada (Ide, Thomson, \& Ditchfield, 1969) and Australia (Cole, 1971). Seroepidemiological studies demonstrated high seropositivity to BAV3 in calves in several countries including the USA (Mattson, Norman \& Dunbar, 1988), Turkey (Ng, Kondov, Deng, Van Eenennaam, \& Neibergs, 2015; Tuncer \& Yeşilbağ, 2015). However, reports of infection associated with IFV and BAV3 have not been identified in Brazil.
The absence of reports of these agents in Brazil does not necessarily indicate that they do not infect cattle herds in the country, but it could simply indicate that they have not been diagnosed so far for not being included in the list of differentials.

Bacterial infections have been frequently associated with secondary bronchopneumonia in BRD. The main bacterial agents are Mannheimia haemolytica, Pasteurella multocida, and Histophilus somni (Fulton, 2009; Panciera \& Confer, 2010; Grissett et al., 2015; Klima, Holman, Ralston, Stanford, \& Zaheer, 2019), and the mollicute, Mycoplasma bovis (Caswell \& Archambault, 2007; Fulton, 2009; López \& Martinson, 2017). Most of the important infectious disease agents associated with the development of BRD worldwide have been diagnosed in herds from Brazil. The main pathological agents most frequently associated with the development of BRD, and the geographic regions found in Brazil are shown in Table 1. Although cattle farming occurs in several geographic regions of Brazil (Headley, Oliveira, \& Cunha, 2020), the data collected suggest that most studies related to the investigation of BRD in Brazil were conducted mainly in the south and southeast regions of the country (Table 1). Additionally, BoHV-1, BVDV, and BRSV are endemic viral agents in most geographic regions of Brazil (Flores et al., 2000; Flores et al., 2005; Dias, Alfieri, Ferreira-Neto, Gonçalves, \& Muller, 2013), resulting in BRD and other clinical manifestations in dairy and beef cattle.

Several studies done in Brazil have demonstrated concomitant action of respiratory agents of BRD (Baptista et al., 2017; Beuttemmuller et al., 2017; Magalhães et al., 2017; Tortorelli et al., 2017; Gaeta, Ribeiro, Alemán, Yoshihara, \& Nassar, 2018; Oliveira 
\& Pelaquim, et al. 2020; Oliveira \& Dall Agnol, et al. 2020) using molecular identification with or without histopathological and immunohistochemical diagnoses. This trend of concomitant infections in BRD is evident in other countries such as in the USA (Fulton et al., 2009; Schneider, Tait, Busby, \& Reecy, 2009; Taylor et al., 2010), Canada (Gagea et al., 2006; Booker, Abutarbush, Morley, Jim, \& Pittman, 2008; Jim, 2009), and Australia (Cusack, McMeniman, \& Lean, 2003; Moore et al., 2015; Hay et al., 2016). These data suggest that mixed infections in BRD are perhaps more frequent than have been reported.

The most commonly accepted model of pathogenesis involves initial viral infection causing primary lung injury and/or immune dysfunction (López \& Martinson, 2017) followed by a bacterial infection. However, $M$. bovis has been associated with singular infection (Oliveira, Pelaquim, et al., 2020), and could be classified as a primary infectious disease agent (Nicholas, 2011; Gershwin et al., 2015; Oliveira, Pelaquim, et al., 2020). This mollicute may predispose cattle to pulmonary infections induced by $P$. multocida (Nicholas, 2011), due to immunosuppression and immunomodulatory effects (Nicholas, 2011; Margineda, Zielinski, Jurado, Alejandra, \& Mozgovoj, 2017). Furthermore, the association of $M$. bovis as a singular agent in the development of BRD has been confirmed in both dairy (Margineda et al., 2017; Oliveira \& Pelaquim, 2020) and beef cattle (Ramírez Romero, Chavarría Martínez, Nevárez Garza, Rodríguez Tovar, \& Dávila Martínez, 2010; Margineda et al., 2017). Consequently, the role of $M$. bovis as a possible primary agent in the development of BRD cannot be excluded.

Diverging from the trend of global literature (Martin, Bateman, Shewen, Rosendal,
\& Bohac, 1989; Fulton, Cook, Step, Confer, \& Saliki, 2002; Murray, More, Sammin, Casey, \& McElroy, 2017), there are few reports of BPIV3 associated with the development of BRD in Brazil. This infectious disease agent was not identified in several studies (Brasil et al., 2013; Baptista et al., 2017; Headley, Okano, Balbo, Marcasso, \& Oliveira, 2017; Oliveira \& Dall Agnol, et al., 2020), but was associated with few cases of mixed infections in cattle from Brazil (Oliveira \& Pelaquim, et al., 2020). A retrospective study done by our group identified singular BPIV-3 infections in only $6.6 \%$ (1/15 of all diagnoses) of interstitial pneumonia (Oliveira \& Pelaquim, et al.,2020). These data suggest that BPIV-3 circulates in cattle herds from Brazil, with possibly low frequencies.

Additionally, there is evidence that ovine gammaherpesvirus-2, OvHV-2 (Headley, Oliveira, \& Cunha, 2020) and HoBi-like pestiviruses (Hoppe etal., 2019) are candidates of emerging pathogens associated with the development of BRD. Recently, OvHV-2 was associated with the occurrence of respiratory disease in a calf infected simultaneously with BVDV, BoHV-1, and Aspergillus fumigatus (Headley, Müller, Oliveira, Duarte, \& Pereira, 2020) and in two adult cattle with interstitial pneumonia (Headley, Oliveira, Li, Lisbôa, \& Queiroz, 2020). The proposed involvement of OvHV-2 in the development of BRD has been reviewed and can be consulted (Headley, Oliveira, \& Cunha, 2020).

\section{Clinical manifestations of BRD}

The first line of defense of the immune system is represented by the respiratory epithelium, which provides mechanical, chemical, and microbiological barriers to 
prevent infection by pathogens associated with BRD (Panciera \& Confer, 2010). In asymptomatic cattle, the upper respiratory tract is colonized by a variety of bacteria, such as $M$. haemolytica, $H$. somni, and $P$. multocida; although these bacteria are part of the normal microbiota of the respiratory system, they are opportunistic and can result in severe respiratory disease (Griffin et al., 2010; Gershwin et al., 2015; Zhang, Hill, Godson, Ngeleka, \& Fernando, 2020). Clinically, the BRD complex includes enzootic pneumonia of calves, a multifactorial etiologic entity that includes disease such as pneumonic mannheimiosis ( $M$. haemolytica), respiratory histophilosis (H. somni), pneumonia by M. bovis, infectious bovine rhinotracheitis (BoHV-1), and viral pneumonia by BPIV-3 and BRSV (Andrews \& Kennedy, 1997; Fulton, 2009; Fulton et al., 2009; Panciera \& Confer, 2010; Klima, Zaheer, Cook, Booker, \& Hendrick, 2014; Francoz et al., 2015; Gershwin et al., 2015; Murray et al., 2017; Zhang et al., 2020).

Clinical signs are usually observed after stressful events. Infection occurs by the inhalation of droplets containing microorganisms, direct contact with infected animals, or ingestion of water or food contaminated with nasal discharge from infected animals (Gagea et al., 2006; Fulton, 2009). Clinical manifestations may include nasal and ocular secretions, anorexia, fever of up to $42^{\circ} \mathrm{C}$, tachypnea, tachycardia, muzzle crusts, cough, dyspnea, and pulmonary rales (Griffin et al., 2010).

Pneumonic mannheimiosis is frequently associated with an acute respiratory disease that occurs a few days or weeks after animals are transported, hence the term "shipping fever" (López \& Martinson, 2017),
M. haemolytica associated with P. multocida can result in fatal pneumonia (Griffin et al., 2010), that is pathologically characterized as severe fibrinous bronchopneumonia (López \& Martinson, 2017).

P. multocida is easily isolated from nasal and pharyngeal secretions of cattle; isolation rates reported in clinically normal cattle are high and range from 20 to $60 \%$ (Griffin et al., 2010), since it is a commensal microorganism (Fulton, 2009). The isolation of $P$. multocida in animals clinically presenting respiratory disease is about two times higher than in healthy animals (Griffin et al., 2010). The development of pneumonia induced by this bacterium is associated with risk factors such as transport, stress, batch mixing, overcrowding, and primary viral or bacterial infections (Dabo, Taylor, \& Confer, 2007).

Respiratory histophilosis is part of a complex of diseases associated with $\mathrm{H}$. somni infection, termed histophilosis (Corbeil, 2007; O'Toole \& Sondgeroth, 2016). This complex consists of several clinical manifestations including thrombotic meningoencephalitis, septicemia, pneumonia, pleuritis, myocarditis, arthritis, conjunctivitis, otitis, and abortions (Corbeil, 2007; O'Toole \& Sondgeroth, 2016). The respiratory form is characterized by fibrinopurulent bronchopneumonia (Corbeil, 2007; O'Toole \& Sondgeroth, 2016; Headley et al., 2017). All clinical manifestations of histophilosis are well known in the USA (Corbeil, 2007; O'Toole, Allen, Hunter, \& Corbeil, 2009; O'Toole \& Sondgeroth, 2016), Australia (Lancaster, McGillivery, Patterson, \& Irwin, 1984; Hick, Read, Lugton, Busfield, \& Dawood, 2012), with few descriptions in Brazil (Headley et al., 2014; Headley, Bracarense, Oliveira, Queiroz, \& Okano, 2015; Headley, \& 
Balbo, 2017; Headley, Pereira, Balbo, Santia, \& Bracarense, 2018). The few cases or outbreaks of pulmonary histophilosis found in Brazil could be associated with the lack of diagnosis or confusion due to the similarity of the pathological findings observed in the lungs of cattle infected by $M$. haemolytica. Considering the multisystemic nature of histophilosis, which often results in mortality in affected animals, feedlot cattle in Brazil may be susceptible to infection since the pathological manifestations are not easily recognized (Headley et al., 2014).

M. bovis is the most common species of Mycoplasma sp. isolated from the lungs of cattle with pneumonia in Europe and North America (Caswell \& Archambault, 2007; Nicholas, 2011), and pulmonary infection is aggravated by the risk factors of BRD (Snowder, Van Vleck, Cundiff, \& Bennett, 2006; Taylor et al., 2010; Hay et al., 2016; Murray, Cassidy, Clegg, Tratalos, \& McClure, 2016; López \& Martinson, 2017; Murray et al., 2017). The respiratory disease associated with infection by $M$. bovis results in clinical manifestations that are similar to other types of pneumonia; these alterations include fever, loss of appetite, nasal discharge, cough, and increased respiratory rate, while in some cases, other clinical manifestations such as otitis media, mastitis, and arthritis can be observed (Maunsell \& Donovan, 2009). Diseases associated with BoHV-1 infection are endemic in most geographical regions of Brazil, with seroprevalence ranging from 11 to 74\% (Dias, Alfieri, Médici, Freitas, \& Ferreira, 2008; Pasqualotto, Sehnem, \& Winck, 2015). However, there are few studies that effectively evaluate the respiratory manifestations associated with infections induced by BoHV-1 in cattle from Brazil.

Depending on the immunological status of the host, BRSV infections may be asymptomatic, with a tendency for greater severity observed in younger cattle. The most frequently observed clinical signs are those of upper airway infection, which may progress to bronchiolitis and interstitial pneumonia (Philippou, Streckert, Otto, Reinhold, \& Elschner, 1996; Sacco, McGill, Pillatzki, Palmer, \& Ackermann, 2014; Caswell \& Williams, 2016). In a study in Denmark, the clinical signs of BRSV infection included nasal secretion, pyrexia, cough, elevated respiratory rate, and marked depression; the affected animals were calves between four and seven months of age (Larsen, Tegtmeier, \& Pedersen, 2001). In Brazil, cough, rales, and dyspnea were observed in calves infected with BRSV (Driemeier et al., 1997).

BPIV-3 infections are commonly associated with discrete or asymptomatic clinical manifestations, mainly in adult animals. However, BPIV-3 predisposes cattle to secondary respiratory infections and consequently, clinical manifestations consistent with BRD will occur (Griffin et al., 2010). In Brazil, few studies have identified the occurrence of BVPI-3 in associated with the development of BRD (Gonçalves et al., 2003; Oliveira, \& Pelaquim, et al., 2020). In one of these studies, where the virus was isolated from a calf, clinical manifestations of pulmonary disease including apathy, fever, tachypnea, and severe serous nasal discharge were reported (Gonçalves et al., 2003). 
Methods and challenges in the diagnosis of the agents of $B R D$

\section{Clinical manifestations}

There are several methods to obtain a diagnosis of BRD. These include the clinical history and laboratory analysis of animal tissues derived from live and dead animals. The diagnosis of BRD is a challenge for the clinician since numerous infectious disease agents are involved. The affected cattle suffer the effects of individual disease agents or more often by a combination of several pathogens (Fulton \& Confer, 2012), so clinical evaluations must include the examination of several animals of the same farm (Caswell, Hewson, Slavić, DeLay, \& Bateman, 2012). The DART system that evaluates the clinical signs (depression, appetite, respiratory, temperature) of pulmonary disease, is recommended for the clinical evaluation of animals with BRD (Wilson, Step, Maxwell, Wagner, \& Richards, 2015), and has been used in several studies by our group (Baptista et al., 2017; Magalhães et al., 2017). However, the isolated use of clinical manifestations is not the best method to diagnose BRD (Fulton \& Confer, 2012). Nevertheless, the clinical history should be concise, effective, and should contain specific observations that allow for the proper interpretation of laboratory results (Caswell et al., 2012). The clinical history should include biological data of the affected animals, duration of manifestations, morbidity and mortality data, common factors among the affected animals, changes in management, environment and climate, immunization history, and use of any quarantine measures at the herd (Cooper \& Brodersen, 2010). Notwithstanding the above, there is always the necessity to discuss each situation with several persons involved to obtain complementary information and/or eliminate conflicting data.

\section{Pathological findings}

The pathological pulmonary findings observed in cattle with BRD are diverse and vary according to the etiology and severity of the disease. In general, infections induced by agents of viral origin result in interstitial pneumonia, mainly in the initial phase of infection (Panciera \& Confer, 2010). As the viral infection progresses, the animal often suffers from immunosuppression, which results in secondary bacterial infection, which is often fatal. Consequently, careful histopathological analysis often identifies the interfaces of the two pulmonary disease. Lesions caused by bacterial infections are more exudative and accumulative, while viral lesions are more inflammatory with corresponding thickening of the alveolar wall (López \& Martinson, 2017).

Suppurative bronchopneumonia is the most common form of BRD seen in young dairy calves and feedlot cattle, and is primarily associated with infection by $P$. multocida, although other bacteria can also produce this lesion (Griffin et al., 2010; Murray et al., 2017). Fibrinous bronchopneumonia is often associated with infections induced by $\mathrm{H}$. somni (Headley et al., 2014; Headley et al., 2018), and M. haemolytica (Griffin et al., 2010; Gershwin et al., 2015; Zhang et al., 2020). Both types of bronchopneumonia are macroscopically characterized by cranioventral consolidation of the affected lungs (Figure 1A). The neutrophilic exudate is predominant in the suppurative manifestation (Figure 1B), 
with predominance of fibrinous exudate in fibrinous bronchopneumonia. However, the two patterns are frequently often seen concomitantly, resulting in fibrinopurulent bronchopneumonia. In acute lesions, the affected pulmonary lobes may vary in color from pink, pink-grey, dark red, red-grey or grey, with interlobular septal edema (Caswell \& Williams, 2016; López \& Martinson, 2017). On the sectioned surface of the pulmonary lobes, brown to gray foci, indicative of bronchiolar and peribronchiolar inflammation (Caswell \& Williams, 2016; López \& Martinson, 2017), can be observed. The remaining areas of the lobules are pink to dark red and represent inflammation, congestion, and atelectasis (Caswell \& Williams, 2016). As lesions become chronic, palpation reveals a more irregular distribution of consolidation and there is more evidence of purulent bronchitis, bronchiectasis, abscess formation, fibrosis, and adhesions (Panciera \& Confer, 2010; Caswell \& Williams, 2016). Microscopically diffuse thickening of alveolar septa can be observed as a result of marked proliferation of type II pneumocytes, leukocytic infiltration within the interstitium and bronchioloalveolar junction, cellular degeneration (suppuration), and occasional intralesional bacterial colonies (Caswell \& Williams, 2016; López \& Martinson, 2017). These histopathological changes often demonstrate the coexistence of multiple infectious agents, viral followed by a secondary bacterial infection.

The lesions observed in the acute phase of bronchointerstitial pneumonia are caused predominantly by viruses (López \& Martinson, 2017). At post-mortem evaluations of cattle with acute interstitial pneumonia, there is usually subcutaneous emphysema on the dorsal region, trachea filled with foamy fluid, and interlobular septa distended by pulmonary edema (Panciera \& Confer, 2010). In the classic manifestation of interstitial pneumonia, exudates are not observed. Consequently, interstitial pneumonia is the most difficult pulmonary lesion to identify during gross evaluation because the affected tissue resembles the normal lung. Microscopically, interstitial pneumonia (Figure $2 \mathrm{~A}$ ) is characterized by hyperplasia of type II pneumocytes, necrotizing bronchiolitis, necrosis of type II pneumocytes, and alveolar edema (Caswell \& Williams, 2016; López \& Martinson, 2017), frequently with an influx of lymphoplasmacytic inflammatory infiltrate. Studies by our group confirmed that all viral agents associated with BRD in Brazil results in interstitial pneumonia (Oliveira, Pelaquim, et al., 2020). In infections associated with BRSV and BPIV-3, intracytoplasmic inclusion bodies and multinucleated syncytia can be identified; syncytia are formed by the fusion of infected bronchiolar epithelial cells (López \& Martinson, 2017).

In an outbreak of BRSV-associated BRD in Rio Grande do Sul, the main macroscopic findings during gross evaluations were widespread alveolar emphysema with foci of atelectasis, interstitial emphysema and marked thickening of the interlobular septa (Driemeier et al., 1997). Microscopically, several syncytial cells were observed within the pulmonary lesion, in addition to dilation of lymphatic vessels, alveolar emphysema, atelectasis, hypertrophy of the peribronchiolar muscle layer, foci of squamous metaplasia of the bronchial and bronchiolar epithelium, mononuclear inflammatory infiltration with foci of infiltration by eosinophils, with fibrinous accumulation in some alveoli, but intracytoplasmic inclusion bodies were not observed (Driemeier et al., 1997). 


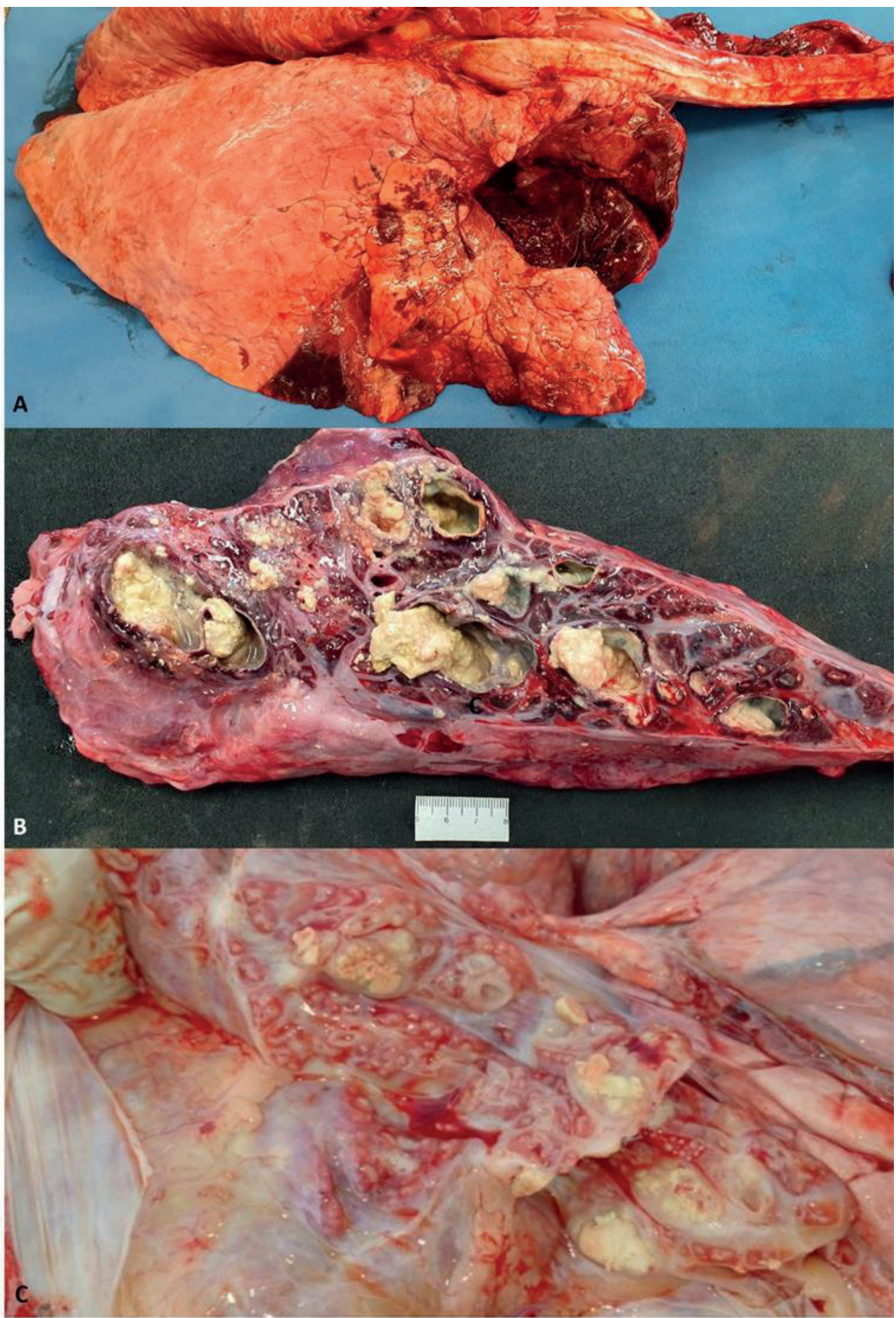

Figure 1. Gross lesions associated with respiratory disease in cattle. There is cranioventral consolidation of the lung of a cow with purulent bronchopneumonia $(A)$ and the accumulation of purulent exudate at the sectioned surface of the lung with bronchiectasis (B). Observe the typical caseonecrotic nodules seen in bronchopneumonia associated with infection by Mycoplasma bovis. (C) 


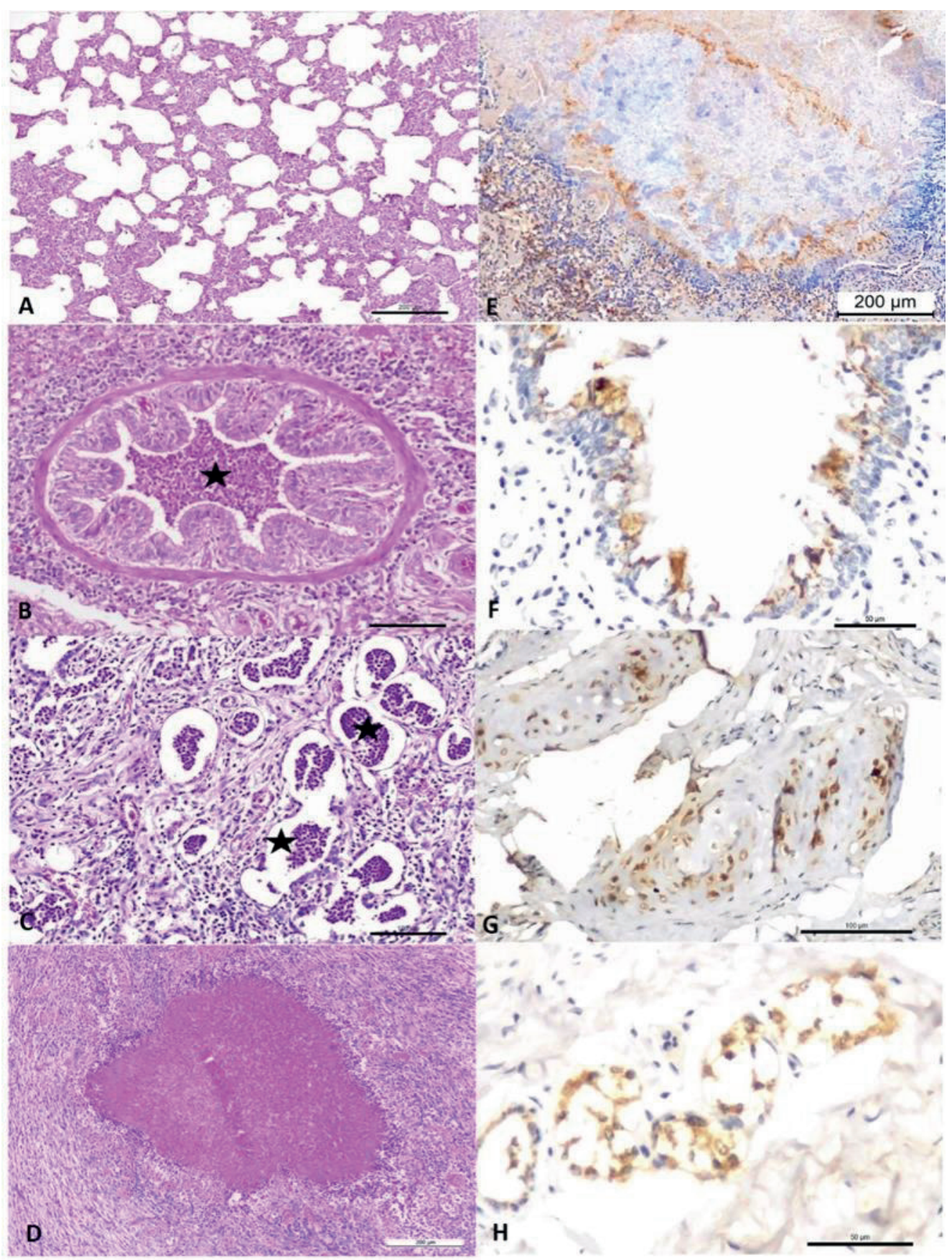

Figure 2. Histopathological and immunohistochemical findings observed in bovine respiratory disease. There is interstitial pneumonia associated with viral infection $(A)$ and the accumulation of neutrophilic exudate (star) within the lung of a cow with purulent bronchopneumonia (B-C). Observe the typical centrally located region of caseonecrotic bronchopneumonia that is characteristic for Mycoplasma bovis (D) and positive immunoreactivity to antigens of $M$. bovis at the rim of the necrotic zone (E). There is positive immunolabeling for antigens of BRSV at the bronchial epithelium $(\mathrm{F})$, for BoHV-1 within chondrocytes of the hyaline cartilage of the bronchus (G), and for BVDV within epithelial cells of the mixed peribronchial glands $(H)$. A-D, Hematoxylin and eosin stain; E-H,

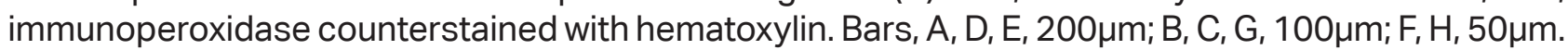


Retrospective studies using immunohistochemistry (IHC) identified BRSV antigens in $24.4 \%(12 / 46)$ of calves with clinical and pathological manifestations of bronchopneumonia from the State of Rio Grande do Sul (Flores et al., 2000), while 34.4\% (11/32) of pulmonary tissues demonstrated BRSV antigens in a study conducted in Paraná (Oliveira, Pelaquim, et al., 2020). However, syncytial cell formation, a key element in the diagnosis of BRSV-induced interstitial pneumonia (Caswell \& Williams, 2016; López \& Martinson, 2017), was observed in only $36.6 \%$ (4/11) of infected animals (Oliveira, Pelaquim, et al., 2020). Interestingly, two animals with apparently normal pulmonary parenchyma but necrotic bronchitis contained intralesional BRSV antigens (Oliveira, Pelaquim, et al., 2020). Consequently, the confirmation of the histological diagnosis of infectious agents associated with the development of BRD should be based not only on histopathological changes but should be associated with analyses that detect intralesional antigens or proteins of the infectious agents such as IHC and in situ hybridization (ISH).

Pathological findings of lesions caused by $M$. bovis may be similar to those of viral infections but tend to progress to a chronic stage characterized by peribronchiolar lymphoid hyperplasia (Rodriguez, Bryson, Ball \& Forster, 1996; Maunsell \& Donovan, 2009). The pathological changes induced by $M$. bovis range from necrosuppurative, caseonecrotic (Figure 1C) to suppurative bronchopneumonia (Nicholas, 2011; Oliveira, Pelaquim, et al., 2020), with caseonecrotic bronchopneumonia being the typical finding associated with infection by M. bovis.
A retrospective study (Oliveira et al., manuscript in preparation) identified intralesional antigens from a malignant catarrhal fever virus (MCFV), probably OvHV2 , in 53.3\% (64/120) of all pathological lesions associated with BRD. Furthermore, this study has demonstrated that antigens of OvHV-2 were associated with pneumonia individually or concomitantly with other agents of BRD. Additionally, the possible participation of OvHV-2 in the pathogenesis of bovine pulmonary disease was proposed (Headley, Oliveira \& Cunha, 2020), and a calf with fungal tracheitis due to Aspergillus fumigatus was concomitantly infected with BVDV, BoHV1, and OvHV-2 (Headley \& Müller, 2020). Collectively, these data suggest that OvHV-2 can act individually or in association with other disease pathogens in the development of BRD and should be included in the differential diagnosis of cattle with pulmonary disease.

Although most infectious disease agents associated with the development of BRD are of bacterial and viral origin, fungi and protozoa can concomitantly infect the lung and produce pulmonary disease. It is of fundamental importance that the person responsible, when requesting a laboratory examination, considers the clinical manifestations and requests a set of laboratory tests to achieve the proper diagnosis of the suspected infectious disease pathogens agents. $A$ list of the main laboratory analyses used in the diagnosis and/or identification of the infectious agents associated with BRD, as well as the advantages and disadvantages, is provided in Table 2. 
Table 2

Comparison of diagnostic methods and/or laboratory identification of organisms related to the development of DRB ${ }^{1}$

\begin{tabular}{|c|c|c|c|}
\hline \multirow{2}{*}{$\begin{array}{l}\text { Diagnostic } \\
\text { methods }\end{array}$} & \multirow{2}{*}{$\begin{array}{l}\text { What is } \\
\text { detected? }\end{array}$} & \multicolumn{2}{|c|}{ Differences } \\
\hline & & Advantages & Disadvantages \\
\hline Serology & Antibody & $\begin{array}{l}\text { Detects vaccine response } \\
\text { and recent or old contact } \\
\text { with the agent. } \\
\text { Most respiratory pathogens } \\
\text { induce a strong antibody } \\
\text { response. } \\
\text { Can be performed on several } \\
\text { animals simultaneously. } \\
\text { Results are processed in less } \\
\text { time when compared to some } \\
\text { tests. }\end{array}$ & $\begin{array}{l}\text { Does not differentiate between vaccine } \\
\text { antibodies and antibodies induced } \\
\text { during infection. } \\
\text { Elevated cost when the number of } \\
\text { samples processed is large. } \\
\text { Does not always indicate the state of } \\
\text { the animal. }\end{array}$ \\
\hline $\begin{array}{l}\text { Culture: nasal, } \\
\text { nasopharynx, } \\
\text { tracheal and } \\
\text { bronchoalveolar } \\
\text { lavage }\end{array}$ & $\begin{array}{l}\text { Bacterial, } \\
\text { viral, and } \\
\text { fungal } \\
\text { organisms }\end{array}$ & $\begin{array}{l}\text { Detects the presence of } \\
\text { colonization and/or active } \\
\text { infection. }\end{array}$ & $\begin{array}{l}\text { Positive culture does not necessarily } \\
\text { imply pulmonary disease/lesion. } \\
\text { Prolonged time to obtain results. } \\
\text { Specialized training is needed to } \\
\text { perform bronchoalveolar lavage. }\end{array}$ \\
\hline $\begin{array}{l}\text { Culture of } \\
\text { pulmonary } \\
\text { tissues/lesion }\end{array}$ & $\begin{array}{l}\text { Bacterial, } \\
\text { viral, and } \\
\text { fungal } \\
\text { organisms }\end{array}$ & $\begin{array}{l}\text { Isolation indicates elevated } \\
\text { concentrations of the agent } \\
\text { within the tissue. } \\
\text { Antimicrobial resistance can } \\
\text { be determined. }\end{array}$ & $\begin{array}{l}\text { Concomitant infections and } \\
\text { antimicrobial therapy can interfere with } \\
\text { the outcome of the results. } \\
\text { Time to obtain the results is extended. }\end{array}$ \\
\hline $\begin{array}{l}\text { Post-mortem } \\
\text { evaluation and } \\
\text { histopathological } \\
\text { examination of } \\
\text { pulmonary lesion }\end{array}$ & $\begin{array}{l}\text { Pathologic } \\
\text { findings } \\
\text { within the } \\
\text { pulmonary } \\
\text { system }\end{array}$ & $\begin{array}{l}\text { The causative agent of } \\
\text { pulmonary disease can } \\
\text { be suggested based on } \\
\text { the pattern of pulmonary } \\
\text { disease. } \\
\text { Evaluation is comprehensive } \\
\text { and can identify disease } \\
\text { or lesions not previously } \\
\text { reported. }\end{array}$ & $\begin{array}{l}\text { Frequently done with few animals. } \\
\text { Animals that have died may not be } \\
\text { representative of the affected herd. } \\
\text { Sample collection and storage } \\
\text { conditions are directly related to the } \\
\text { quality and efficiency of the diagnosis. } \\
\text { Specialized technical professional is } \\
\text { needed. }\end{array}$ \\
\hline $\begin{array}{l}\text { Immunohisto- } \\
\text { chemical } \\
\text { evaluation of } \\
\text { pulmonary lesion }\end{array}$ & $\begin{array}{l}\text { Intralesional } \\
\text { antigen in } \\
\text { the affected } \\
\text { pulmonary } \\
\text { tissue }\end{array}$ & $\begin{array}{l}\text { In situ location of the } \\
\text { infectious disease pathogen } \\
\text { within the lesion. } \\
\text { Strong evidence that the } \\
\text { infectious agent induced the } \\
\text { disease. } \\
\text { Recommended for } \\
\text { retrospective studies using } \\
\text { formalin fixed paraffin } \\
\text { embedded tissues }\end{array}$ & $\begin{array}{l}\text { Sensitivity and specificity depend } \\
\text { on the availability of polyclonal } \\
\text { hyperimmune serum or commercial } \\
\text { monoclonal antibody for the specific } \\
\text { infectious disease agent. } \\
\text { Prolonged and/or inadequate fixation } \\
\text { could affect the result. } \\
\text { Antigen retrieval must be enhanced for } \\
\text { tissues fixed over prolonged periods. } \\
\text { Specialized technical professional is } \\
\text { needed. }\end{array}$ \\
\hline
\end{tabular}

continue... 
...continuation

\begin{tabular}{|c|c|c|c|}
\hline $\begin{array}{l}\text { In situ } \\
\text { hybridization } \\
\text { of pulmonary } \\
\text { tissue/lesion }\end{array}$ & $\begin{array}{l}\text { Genomic } \\
\text { region of the } \\
\text { infectious } \\
\text { disease } \\
\text { agent within } \\
\text { the lesion }\end{array}$ & $\begin{array}{l}\text { In situ identification of the } \\
\text { infectious agent within the } \\
\text { lesion. } \\
\text { Strong evidence that the } \\
\text { infectious agent caused the } \\
\text { disease. } \\
\text { No specific mono antiserum } \\
\text { or monoclonal antibodies are } \\
\text { required. }\end{array}$ & $\begin{array}{l}\text { Dependent on the specific genomic } \\
\text { region of the pathogen for the } \\
\text { development of a specific primer. } \\
\text { Elevated cost to acquire commercial } \\
\text { reagents. } \\
\text { Specialized technical professional is } \\
\text { needed. }\end{array}$ \\
\hline $\begin{array}{l}\text { PCR/RT- } \\
\text { PCR - nasal, } \\
\text { nasopharynx, or } \\
\text { trachea swabs or } \\
\text { bronchoalveolar } \\
\text { lavage collection }\end{array}$ & $\begin{array}{l}\text { Genetic } \\
\text { material } \\
\text { of the } \\
\text { infectious } \\
\text { disease } \\
\text { agent }\end{array}$ & $\begin{array}{l}\text { Confirms that the amplified } \\
\text { infectious disease agent is } \\
\text { present in the sample. }\end{array}$ & $\begin{array}{l}\text { Does not differentiate between } \\
\text { concomitant, subclinical, or accidental } \\
\text { infection from natural infection or } \\
\text { vaccination. } \\
\text { Does not always detect the agent in } \\
\text { the sample. } \\
\text { Does not determine resistance to } \\
\text { antimicrobials. } \\
\text { High cost to purchase reagents. }\end{array}$ \\
\hline $\begin{array}{l}\text { PCR/RT-PCR - } \\
\text { pulmonary lesion } \\
\text { and from formalin } \\
\text { fixed paraffin } \\
\text { embedded tissue } \\
\text { fragments }\end{array}$ & $\begin{array}{l}\text { Genomic } \\
\text { region of } \\
\text { the agent }\end{array}$ & $\begin{array}{l}\text { Confirms that the infectious } \\
\text { disease agent is associated } \\
\text { with the disease/lesion. }\end{array}$ & $\begin{array}{l}\text { May not represent the causative } \\
\text { infectious agent or differentiate } \\
\text { between natural infection and modified } \\
\text { live vaccine. } \\
\text { Additional analysis(es) needed to } \\
\text { determine the relationship between the } \\
\text { agent amplified and tissue damage. } \\
\text { Formalin fixation and/or paraffin } \\
\text { embedding affects the amplification of } \\
\text { the genetic material of the pathogen. } \\
\text { Elevated cost to acquire reagents. }\end{array}$ \\
\hline $\begin{array}{l}\text { Multiplex } \\
\text { PCR- nasal, } \\
\text { nasopharynx, or } \\
\text { trachea swabs or } \\
\text { bronchoalveolar } \\
\text { lavage collection }\end{array}$ & $\begin{array}{l}\text { Genomic } \\
\text { regions } \\
\text { of several } \\
\text { infectious } \\
\text { disease } \\
\text { agents }\end{array}$ & $\begin{array}{l}\text { Confirms that one or more } \\
\text { infectious disease agent is } \\
\text { associated with the disease/ } \\
\text { lesion. }\end{array}$ & $\begin{array}{l}\text { May not represent the causative } \\
\text { infectious agent or differentiate } \\
\text { between natural infection and modified } \\
\text { live vaccine. } \\
\text { Additional analysis(es) needed to } \\
\text { determine the relationship between the } \\
\text { agent amplified and tissue damage. } \\
\text { Elevated cost to acquire reagents. }\end{array}$ \\
\hline $\begin{array}{l}\text { Multiplex PCR of } \\
\text { the pulmonary } \\
\text { lesion }\end{array}$ & $\begin{array}{l}\text { Genomic } \\
\text { regions } \\
\text { of several } \\
\text { infectious } \\
\text { disease } \\
\text { agents }\end{array}$ & $\begin{array}{l}\text { Confirms that one or more } \\
\text { infectious disease agent is } \\
\text { associated with the disease/ } \\
\text { lesion. }\end{array}$ & $\begin{array}{l}\text { May not represent the causative } \\
\text { infectious agent or differentiate } \\
\text { between natural infection and modified } \\
\text { live vaccine. } \\
\text { Additional analysis(es) needed to } \\
\text { determine the relationship between the } \\
\text { agent amplified and tissue damage. } \\
\text { Elevated cost to acquire reagents. }\end{array}$ \\
\hline
\end{tabular}

'Adapted from Caswell et al., 2012; Fulton \& Confer, 2012. 


\section{Serology and isolation of the agent}

Serology is widely used to detect antibodies of infectious agents associated with BRD in Brazil (Gonçalves et al., 1993; Dias et al., 2013; Gaeta, Ribeiro, Alemán, Yoshihara, \& Marques, 2018), and worldwide (Martin et al., 1989; Tuncer \& Yeşilbağ, 2015; Luo et al., 2017). Seroepidemiological analyses are fundamental to determine the presence or spread of a particular agent(s) in herds; however, they do not always confirm whether animals are actually infected (Fulton \& Confer, 2012). In general, seroepidemiological evaluations are effective in determining the agents associated with outbreaks of BRD (Caswell et al., 2012).

The isolation of bacterial agents from secretions obtained from the nasal cavity, nasopharyngeal region, and bronchoalveolar lavage is usually done in live cattle (Fulton \& Confer, 2012), while pulmonary tissues can be collected during post-mortem analysis (Caswell et al., 2012; Fulton \& Confer, 2012). It is essential that the collected sample be refrigerated, but not frozen (Fulton \& Confer, 2012), and that the sample be transported to the diagnostic laboratory as soon as possible. In contrast, biological samples collected for viral identification using different molecular biology techniques can be frozen $\left(-20^{\circ} \mathrm{C}\right.$ or preferably, $-80^{\circ} \mathrm{C}$ ) before being sent to the diagnostic laboratory. Viral isolation targets the growth of viral agents in specific cell cultures from collected samples, resulting in characteristic cytopathic effects observed under the microscope (Leland \& French, 1988; Fulton \& Confer, 2012). However, the identity of the virus observed should be confirmed by another diagnostic technique (Leland \& French, 1988; Fulton \& Confer, 2012); several passages in cell culture are often required (Leland \& French, 1988). Currently, viral isolation is being replaced by molecular biology techniques in most diagnostic laboratories.

\section{Molecular characterization}

There are several molecular methods used as tests for the identification of infectious disease agents from biological samples (collected in vivo or post-mortem) from cattle with BRD, that are being used frequently in studies worldwide. These tests confirm the presence of the amplified agents in the analyzed sample and, consequently, infection in the affected animal (Fulton \& Confer, 2012). However, the presence of the agent identified by molecular biology tests does not necessarily indicate a morphological alteration resulting in cellular changes and finally a lesion and/or disease. Therefore, it is recommended to use histological and molecular analyses in combination when using pulmonary samples to confirm the participation of the agent found in the development of the pulmonary disease (Fulton \& Confer, 2012; Maes, Langohr, Wise, Smedley, Thaiwong 2014). Additionally, one of the limitations of molecular tests for the identification of bacterial agents, is the inability to provide information related to bacterial resistance and susceptibility (Fulton \& Confer, 2012); consequently, animals on the property cannot be treated effectively and adequately.

The greatest problem in the diagnosis of agents associated with BRD is the molecular identification of pulmonary samples derived from formalin-fixed paraffin-embedded tissues. Molecular results from these tissues could be negatively affected for several reasons, including: 1) prolonged time of fixation in formalin solution; 2) amount of fixative 
solution relative to tissue; 3) no buffering or inadequate buffering of formalin solution; 4) degradation of genetic material (DNA or RNA) of the infectious agent; 5) storage time of the embedded tissue; and 6) the quality of paraffin used (Maes et al., 2014). However, the molecular amplification of any infectious agent from these lung tissues with the characteristic histological change confirms the participation of the amplified agent in the development of the pulmonary disease (Fulton \& Confer, 2012). Consequently, all molecular identification from lung tissues must be accompanied by diagnostic methods such as histopathology, $\mathrm{IHC}$, and/or ISH, to effectively differentiate between infection and disease (Maes et al., 2014).

Adequate post-mortem evaluation of pulmonary tissues should be performed for cattle at various stages of the disease from the same property or affected herd and must include asymptomatic animals (Cooper \& Brodersen, 2010). Ideally, the lung should be evaluated in situ on the animal carcass; consequently, the pattern of pulmonary disease can be established and associated with a spectrum of infectious agents (Caswell et al., 2012). Lung fragments sent for pathological diagnosis should be acquired from several pulmonary lobes, containing normal and affected tissue.

Histopathological evaluation is essential to recognize the pattern of tissue injury induced by infectious disease agents, as the associated patterns of most of the major pathogens of BRD are known. Additionally, there is a strong association between the histological pattern of pulmonary disease and the related infectious agents (Zhang et al., 2020). Interstitial pneumonia (Figure 2A) is the pattern of pulmonary injury characteristic of infections induced primarily by viral disease agents (Caswell \& Williams, 2016; López \& Martinson, 2017). However, histopathological evaluation alone is not sufficient to indicate the associated agent. Suppurative bronchopneumonia (Figure $2 \mathrm{~B}-\mathrm{C}$ ) is the characteristic manifestation of some bacterial agents (Caswell etal., 2012; López \& Martinson, 2017) associated with BRD. A metagenomic study identified multiple associations between pulmonary disease patterns and bacterial agents: $H$. somni and $M$. haemolytica with suppurative bronchopneumonia (Zhang et al., 2020). However, while caseonecrotic bronchopneumonia (Figure 2D) is the classic pattern of chronic M. bovis-induced pneumonia (Maunsell \& Donovan, 2009; Margineda et al., 2017; Oliveira \& Pelaquim, et al., 2020), other histopathological manifestations of bronchopneumonia and bronchointerstitial pneumonia have been observed (Caswell \& Archambault, 2007; Nicholas, 2011; Oliveira \& Pelaquim, et al., 2020).

Consequently, histopathological patterns alone should not be used to differentiate between infectious agents of BRD, since most viral disease pathogens induce interstitial pneumonia (Caswell \& Williams, 2016; López \& Martinson, 2017), further studies detailing the histologic lesions induced by each agent in the pulmonary tissue of cattle are needed. There are indications that BoHV-1-induced pulmonary disease can be differentiated from that associated with other viral agents due to bronchial angiogenesis, associated with the formation of granulation tissue, observed in cattle with BRD (Oliveira, Pelaquim, et al., 2020). However, additional studies are needed to confirm these associations between histological changes with specific viral agents of BRD. 
The diagnosis of the agents of BRD using analyses that detect intralesional antigens or proteins, such as $\mathrm{IHC}$ and $\mathrm{ISH}$, is perhaps one of the most efficient methods to define the association between infectious agents, the induced morphological alteration, and subsequent clinical manifestation. Additionally, the results of direct culture, IHC, and ISH are more easily interpreted regarding the cause and effect associated with any infectious agent of BRD (Fulton \& Confer, 2012), is widely used to detect intralesional antigens of a vast majority of infectious agents (Figure 2E-H) of BRD in national (Flores et al., 2000; Oliveira, Pelaquim, et al., 2020), and international (Gagea et al., 2006; Ramírez Romero et al., 2010; Margineda et al., 2017) studies. Among the disadvantages of IHC (Fulton \& Confer, 2012), availability and cost of monoclonalorpolyclonalantibodies, especially for emerging agents (Fulton \& Confer, 2012) must be highlighted. Another limiting factor of $\mathrm{IHC}$ is that prolonged fixation in formalin solution could affect the antigenic recovery and the expected result. Consequently, it is recommended for prolonged maintenance, that tissues already fixed in formalin solution be maintained in $70 \%$ alcohol solution, as alcohol interrupts the formation of cross-links and facilitates the detection of antigens for further evaluation by IHC (Ramos-Vara \& Miller, 2014).

\section{Prevention and Control of $B R D$}

The implementation of BRD prophylaxis and control systems could substantially reduce economic losses due to morbidity and mortality in cattle. Control of BRD can best be accomplished by focusing on integrated programs of vaccination against pathogens causing BRD and improvements in nutritional status, especially for calves exposed to stress conditions.

Among the prevention strategies, vaccination against the main causative agents of BRD plays an important role in feedlot cattle, since animals immunized animals and booster vaccination prior to entering the feedlot were found to be 2.5 times less likely to develop BRD than those that received vaccination when entering the feedlot (Magalhães et al., 2017).

Another important factor is the reduction of stress caused by management practices (Urban-Chmiel \& Grooms, 2012). Management that advocates the maintenance of animal welfare is considered an important tool for disease prevention, especially in confined cattle (Tucker, Coetzee, Stookey, Thomson, \& Grandin, 2015). Measures to reduce exposure to pathogens of BRD should be taken by reducing the risk of infected animals being introduced into the herd by monitoring introduced animals via quarantine and the isolating of sick cattle (Urban-Chmiel \& Grooms, 2012).

Mass treatment is based on the administration of antibiotics with prolonged action for the control of bovine respiratory disease. This practice is quite common and has proven effective in reducing morbidity and mortality rates arising from BRD (Taylor et al., 2010).

In Brazil, a study using oxytetracycline and tildipirosin in metaphylactic protocols for prophylaxis of BRD demonstrated that these drugs were efficient in reducing both morbidity and lung lesions in feedlot cattle (Magalhães et al., 2017). Florfenicol has also been shown to be efficient in the metaphylaxis of BRD in feedlot cattle, reducing clinical manifestations 
and improving the development of the animals economically viable (Catry, Duchateau, Van de Ven, Laevens, \& Opsomer, 2008).

\section{Conclusion}

Bovine respiratory disease is endemic in the main cattle producing regions of Brazil. The principal causative agents identified in association with BRD in cattle from Brazil are BRSV, BVDV, BoHV-1, and $M$. bovis. Nevertheless, there are emerging evidence that OvHV-2 and $\mathrm{HoBi}$-like pestivirus may be important agents in the development of BRD. Although, initial studies have identified high mortality and morbidity rates resulting in elevated costs related to economic losses in affected cattle from Brazil, additional surveys from other geographical regions are necessary to understand the exact situation locally.

\section{Acknowledgements}

Oliveira, T.E.S. is the recipient of a graduate fellowship from the National Counsel of Scientific and Technological Development (CNPq; Brazil). Headley, S.A. is the recipient of the National Counsel of Scientific and Technological Development (CNPq; Brazil) fellowship.

\section{References}

Andrews, G. A., \& Kennedy, G. A. (1997). Respiratory diagnostic pathology. The Veterinary Clinics of North America. Food Animal Practice, 13(3), 515-547. doi: 10. 1016/s0749-0720(15)30312-1
Apley, M. (2006). Bovine respiratory disease: pathogenesis, clinical signs, and treatment in lightweight calves. The Veterinary Clinics of North America. Food Animal Practice, 22(2), 399-411. doi: 10.1016/j. cvfa.2006.03.009

Baptista, A. L., Rezende, A. L., Fonseca, P. A., Nogueira, G. M., Headley, S. A., Menezes, G. L., Alfieri, A. A., \& Saut, J. P. E. (2017). Bovine respiratory disease complex associated mortality and morbidity rates in feedlot cattle from southeastern Brazil. Journal of Infection in Developing Countries, 11(10), 791-799. doi: 10.3855/jidc.9296

Bauermann, F. V., Ridpath, J. F., Weiblen, R., \& Flores, E. F. (2013). HoBi-like viruses: an emerging group of pestiviruses. Journal of Veterinary Diagnostic Investigation, 25(1), 6-15. doi: 10.1177/1040638712473103

Beuttemmuller, E. A., Alfieri, A. F., Headley, S. A., \& Alfieri, A. A. (2017). Brazilian strain of bovine respiratory coronavirus is derived from dual enteric and respiratory tropism. Genetics and Molecular Research, 16(2), gmr16029580. doi: 10.4238/gmr16029580

Blakebrough-Hall, C., McMeniman, J. P., \& González, L. A. (2020). An evaluation of the economic effects of bovine respiratory disease on animal performance, carcass traits, and economic outcomes in feedlot cattle defined using four BRD diagnosis methods. Journal of Animal Science, 98(2), 1-11. doi: 10.10 93/jas/skaa005

Booker, C. W., Abutarbush, S. M., Morley, P. S., Jim, G. K., Pittman, T. J., Schunicht, O. C.,...Janzen, E. D. (2008). Microbiological and histopathological findings in cases of fatal bovine respiratory disease of feedlot 
cattle in Western Canada. Canadian Veterinary Journal, 49(5), 473-481. Retrieved from https://www.ncbi.nlm.nih. gov/pmc/articles/PMC2359492/pdf/cvj49 pg473.pdf

Brasil, N. D. A., Hinnah, F. L., Fiss, L., Sallis, E. S. V., Grecco, F. B., Ladeira, S. R. L., MarcolongoPereira, C., \& Schild, A. L. (2013). Doenças respiratórias em bezerros na região sul do Rio Grande do Sul: estudo retrospectivo de 33 surtos. Pesquisa Veterinária Brasileira, 33(6), 745-751. doi: 10.1590/ S0100-736X2013000600010

Caswell, J. L., \& Archambault, M. (2007). Mycoplasma bovis pneumonia in cattle. Animal Health Research Reviews, 8(2), 161186. doi: $10.1017 / s 1466252307001351$

Caswell, J. L., Hewson, J., Slavić, Đ., DeLay, J., \& Bateman, K. (2012). Laboratory and postmortem diagnosis of bovine respiratory disease. Veterinary Clinics of North America. Food AnimalPractice, 28(3), 419-441. doi: 10.1016/j.cvfa.2012.07.004

Caswell, J. L., \& Williams, K. J. (2016). Respiratory system. In: M. G. Maxie (Ed.), Jubb, Kennedy, and Palmer's Pathology of domestic animals (pp. 465-591). Pennsylvania, PA: Saunders/Elsevier.

Catry, B., Duchateau, L., Van de Ven, J., Laevens, H., Opsomer, G., Haesebrouck, F., \& De Kruif, A. (2008). Efficacy of metaphylactic florfenicol therapy during natural outbreaks of bovine respiratory disease. Journal of Veterinary Pharmacology and Therapeutics, 31(5), 479-487. doi: 10.11 11/j.1365-2885.2008.00981.x

Ceribasi, A. O., Ozkaraca, M., Ceribasi, S., \& Ozer, H. (2014). Histopathologic, immunoperoxidase immunofluorescent examinations on natural cattle pneumonia originated from parainfluenza type 3, respiratory syncytial virus, adenovirus type 3 and herpesvirus type 1. Revue de Médecine Vétérinaire, 165(1), 201-212.

Cole, A. M. (1971). Experimental adenovirus pneumonia in calves. Australian Veterinary Journal, 47(7), 306-311. doi: 10.1111/j. 1751-0813.1971.tb15499.x

Cooper, V. L., \& Brodersen, B. W. (2010). Respiratory disease diagnostics of cattle. Veterinary Clinics of North America. Food Animal Practice, 26(2), 409-416. doi: 10. 1016/j.cvfa.2010.04.009

Corbeil, L. B. (2007). Histophilus somni hostparasite relationships. Animal Health Research Reviews, 8(2), 151-160. doi: 10. $1017 / S 1466252307001417$

Coutinho, A. d. S., Oliveira, J. P., Fo., Silva, D. P. G., Oliveira, A. P., Marcondes, J. S., Chiacchio, S. B.,.,... Gonçalves, R. C. (2009). Mannheimiose pulmonar experimental em bezerros: swab nasal e nasofaringeano como auxílio diagnóstico. Pesquisa Veterinária Brasileira, 29(1), 83-88. doi: 10.1590/S0100-736X2009000100013

Cusack, P., McMeniman, N., \& Lean, I. (2003). The medicine and epidemiology of bovine respiratory disease in feedlots. Australian Veterinary Journal, 81(8), 480-487. doi: 10.1111/j.1751-0813.2003.tb13 367.x

Dabo, S. M., Taylor, J. D., \& Confer, A. W. (2007). Pasteurella multocida and bovine respiratory disease. Animal Health Research Reviews, 8(2), 129-150. doi: 10. $1017 / s 1466252307001399$ 
Dane, H., Duffy, C., Guelbenzu, M., Hause, B., Fee, S., Forster, F., McMenamy, M. J., \& Lemon, K. (2019). Detection of influenza $D$ virus in bovine respiratory disease samples, UK. Transboundary and Emerging Diseases, 66(5), 2184-2187. doi: 10.1111/tbed.13273

Decaro, N., Mari, V., Pinto, P., Lucente, M. S., Sciarretta, R., Cirone, F.,... Buonavoglia, C. (2012). Hobi-like pestivirus: both biotypes isolated from a diseased animal. Journal of General Virology, 93(9), 1976-1983. doi: 10.1099/vir.0.044552-0

Dias, F. C., Médici, K. C., Alexandrino, B., Medeiros, A. S. R., Alfieri, A. A., \& Samara, S. I. (2010). Occurrence of persistently infected animals with bovine viral diarrhoea virus in cattle herds from the States of Minas Gerais and São Paulo, Brazil. Pesquisa Veterinária Brasileira, 30(11), 933-939. doi: 10.1590/S0100-73 6X2010001100006

Dias, J. A., Alfieri, A. A., Médici, K. C., Freitas, J. C., Ferreira, J. S. Neto, \& Müller, E. E. (2008). Fatores de risco associados à infecção pelo herpesvírus bovino 1 em rebanhos bovinos da região Oeste do Estado do Paraná. Pesquisa Veterinária Brasileira, 28(3), 161-168. Retrieved from: https:// www.scielo.br/pdf/pvb/v28n3/06.pdf

Dias, J. A., Alfieri, A. A., Ferreira-Neto, J. S., Gonçalves, V. S., \& Muller, E. E. (2013). Seroprevalence and risk factors of bovine herpesvirus 1 infection in cattle herds in the state of Paraná, Brazil. Transboundary and Emerging Diseases, 60(1), 39-47. doi: 10.1111/j.1865-1682.2012.01316.x
Driemeier, D., Gomes, M. J. P., Moojen, V., Arns, C. W., Vogg, G., Kessler, L., \& Costa, U. M. D. (1997). Manifestação clínico-patológica de infecção natural pelo vírus respiratório sincicial bovino (BRSV) em bovinos de criação extensiva no Rio Grande do Sul, Brasil. Pesquisa Veterinária Brasileira, 17(2), 77-81. doi: 10.1590/S0100-736X19 97000200006

Dubrovsky, S. A., Van Eenennaam, A. L., Karle, B. M., Rossitto, P. V., Lehenbauer, T. W., \& Aly, S. S. (2019). Bovine respiratory disease (BRD) cause-specific and overall mortality in preweaned calves on California dairies: The BRD 10K study. Journal of Dairy Science, 102(8), 7320-7328. doi: 10.3168/ jds. 2018-15463

Ferguson, L., Eckard, L., Epperson, W. B., Long, L. P., Smith, D., Huston, C.,... Wan, $X$. F. (2015). Influenza D virus infection in Mississippi beef cattle. Virology, 486(12), 28-34. doi: 10.1016/j.virol.2015.08.030

Flores, E. F., Weiblen, R., Medeiros, M., Botton, S. A., Irigoyen, L. F., Driemeier, D., Schuch, L. F., \& Moraes, M. (2000). A retrospective search for bovine respiratory syncytial virus (BRSV) antigens in histological specimens by immunofluorescence and immunohistochemistry. Pesquisa Veterinária Brasileira, 20(4), 139-143. doi: 10.1590/S0100-736X2000000400002

Flores, E. F., Weiblen, R., Vogel, F. S. F., Roehe, P. M., Alfieri, A. A., \& Pituco, E. M. (2005). A infecção pelo vírus da diarréia viral bovina (BVDV) no Brasil: histórico, situação atual e perspectivas. Pesquisa Veterinária Brasileira, 25(3), 125-134. doi: 10.1590/ S0100-736X2005000300002 
Francoz, D., Buczinski, S., Belanger, A. M., Forte, G., Labrecque, O., Tremblay, D., Wellemans, V., \& Dubuc, J. (2015). Respiratory pathogens in Quebec dairy calves and their relationship with clinical status, lung consolidation, and average daily gain. Journal of Veterinary Internal Medicine, 29(1), 381-387. doi: 10.1111/ jvim. 12531

Fulton, R. W., Purdy, C. W., Confer, A. W., Saliki, J. T., Loan, R. W., Briggs, R. E., \& Burge, L. J. (2000). Bovine viral diarrhea viral infections in feeder calves with respiratory disease: interactions with Pasteurella spp., parainfluenza-3 virus, and bovine respiratory syncytial virus. Canadian Journal of Veterinary Research, 64(3), 151-159. Retrieved from http://www.ncbi. nlm.nih.gov/pmc/articles/PMC1189606/

Fulton, R. W., Cook, B. J., Step, D. L., Confer, A. W., Saliki, J. T., Payton, M. E.,... Blood, K. S. (2002). Evaluation of health status of calves and the impact on feedlot performance: assessment of a retained ownership program for postweaning calves. Canadian Journal of Veterinary Research, 66(3), 173-180. Retrieved from https:// pubmed.ncbi.nlm.nih.gov/12146889

Fulton, R. W., Briggs, R. E., Payton, M. E., Confer, A. W., Saliki, J. T., Ridpath, J. F., Burge, L. J., \& Duff, G. C. (2004). Maternally derived humoral immunity to bovine viral diarrhea virus (BVDV) 1a, BVDV1b, BVDV2, bovine herpesvirus-1, parainfluenza-3 virus bovine respiratory syncytial virus, Mannheimia haemolytica and Pasteurella multocida in beef calves, antibody decline by half-life studies and effect on response to vaccination. Vaccine, 22(5-6), 643-649. doi: 10.1016/j.vaccine.2003.08.033
Fulton, R. W. (2009). Bovine respiratory disease research (1983-2009). Animal Health Research Reviews, 10(2), 131-139. doi: $10.1017 / \mathrm{s} 146625230999017 x$

Fulton, R. W., Blood, K. S., Panciera, R. J., Payton, M. E., Ridpath, J. F., Confer, A. W.,... Reck, A. (2009). Lung pathology and infectious agents in fatal feedlot pneumonias and relationship with mortality, disease onset, and treatments. Journal of Veterinary Diagnostic Investigation, 21(4), 464-477. doi: 10.1177/104063870902100407

Fulton, R. W., Step, D. L., Wahrmund, J., Burge, L. J., Payton, M. E., Cook, B. J.,... Confer, A. W. (2011). Bovine coronavirus (BCV) infections in transported commingled beef cattle and sole-source ranch calves. Canadian Journal of Veterinary Research, 75(3), 191-199. Retrieved from http://www. ncbi.nlm.nih.gov/pmc/articles/PMC31 22965/

Fulton, R. W., \& Confer, A. W. (2012). Laboratory test descriptions for bovine respiratory disease diagnosis and their strengths and weaknesses: Gold standards for diagnosis, do they exist? Canadian Veterinary Journal, 53(7), 754-761. Retrieved from http://www.ncbi.nlm.nih.gov/pmc/articles/ PMC3377458/

Gaeta, N. C., Ribeiro, B. L. M., Alemán, M. A. R., Yoshihara, E., Marques, E. C., Hellmeister, A. N., Pituco, E. M., \& Gregory, L. (2018). Serological investigation of antibodies against respiratory viruses in calves from Brazilian family farming and their relation to clinical signs of bovine respiratory disease. Pesquisa Veterinária Brasileira, 38(4), 642-648. doi: 10.1590/1678-5150pvb-5234 
Gaeta, N. C., Ribeiro, B. L. M., Alemán, M. A. R., Yoshihara, E., Nassar, A. F. C., Marques, L. M., Timenetsky, J., \& Gregory, L. (2018). Bacterial pathogens of the lower respiratory tract of calves from Brazilian rural settlement herds and their association with clinical signs of bovine respiratory disease. Pesquisa Veterinária Brasileira, 38(3), 374-381. doi: 10.1590/1678-5150-PVB-5323

Gagea, M. I., Bateman, K. G., van Dreumel, T., McEwen, B. J., Carman, S., Archambault, M., Shanahan, R. A., \& Caswell, J. L. (2006). Diseases and pathogens associated with mortality in Ontario beef feedlots. Journal of Veterinary Diagnostic Investigation, 18(1), 18-28. Retrieved from https:// journals.sagepub.com/doi/pdf/10.1177/ 104063870601800104

Gershwin, L. J., Van Eenennaam, A. L., Anderson, M. L., McEligot, H. A., Shao, M. X., Toaff-Rosenstein, R.,... Womack, J. (2015). Single pathogen challenge with agents of the bovine respiratory disease complex. PLoS One, 10(11), e0142479. doi: 10.1371/journal.pone.0142479

Gonçalves, D. A., Spilki, F. R., Chiminazzo, C., Oliveira, M. A., Franco, A. C., \& Roehe, P. M. (2003). Isolamento do vírus parainfluenza bovino tipo 3 no Rio Grande do Sul, Brasil. Ciência Rural, 33(5), 953-956. doi: 10.1590/S0103-84782003000500025

Gonçalves, I., Simanke, A., Jost, H., Hôtzel, I., Soglio, A., \& Moojen, V. (1993). Detection of bovine respiratory syncytial virus in calves of Rio Grande do Sul, Brazil. Ciência Rural, 23(3), 389-390. doi: 10.1590/S0103-8478 1993000300029

Griffin, D., Chengappa, M. M., Kuszak, J., \& McVey, D. S. (2010). Bacterial pathogens of the bovine respiratory disease complex. Veterinary Clinics of North America. Food Animal Practice, 26(2), 381-394. doi: 10. 1016/j.cvfa.2010.04.004

Grissett, G. P., White, B. J., \& Larson, R. L. (2015). Structured literature review of responses of cattle to viral and bacterial pathogens causing bovine respiratory disease complex. Journal of Veterinary Internal Medicine, 29(3), 770-780. doi: 10.1111/ jvim. 12597

Hay, K. E., Morton, J. M., Mahony, T. J., Clements, A. C. A., \& Barnes, T. S. (2016). Associations between animal characteristic and environmental risk factors and bovine respiratory disease in Australian feedlot cattle. Preventive Veterinary Medicine, 125(3), 66-74. doi: 10.1016/j.prevetmed.2016. 01.013

Headley, S. A., Oliveira, V. H., Figueira, G. F., Bronkhorst, D. E., Alfieri, A. F., Okano, W., \& Alfieri, A. A. (2013). Histophilus somni-induced infections in cattle from Southern Brazil. Tropical Animal Health and Production, 45(7), 1579-1588. doi: 10. 1007/s11250-013-0402-7

Headley, S. A., Alfieri, A. F., Oliveira, V. H., Beuttemmuller, E. A., \& Alfieri, A. A. (2014). Histophilus somni is a potential threat to beef cattle feedlots in Brazil. Veterinary Record, 175(10), 249. doi: 10.11 36/ vr.102562.

Headley, S. A., Bracarense, A. P. F. R. L., Oliveira, V. H. S., Queiroz, G. R., Okano, W., Alfieri, A. F.,... Alfieri, A. A. (2015). Histophilus somniinduced thrombotic meningoencephalitis in cattle from northern Paraná, Brazil. Pesquisa Veterinária Brasileira, 35(4), 329336. doi: 10.1590/S0100-736X20150004 00003 
Headley, S. A., Balbo, L. C., Alfieri, A. F., Saut, J. P. E., Baptista, A. L., \& Alfieri, A. A. (2017). Bovine respiratory disease associated with Histophilus somni and bovine respiratory syncytial virus in a beef cattle feedlot from Southeastern Brazil. Semina: Ciências Agrárias, 38(1), 283-294. doi: 10.5433/1679-0359.2017v38n1p283

Headley, S. A., Okano, W., Balbo, L. C., Marcasso, R. A., Oliveira, T. E., Alfieri, A. F.,... Alfieri, A. A. (2017). Molecular survey of infectious agents associated with bovine respiratory disease in a beef cattle feedlot in southern Brazil. Journal of Veterinary Diagnostic Investigation, 30(2), 249-251. doi: 10.11 77/1040638717739945

Headley, S. A., Pereira, A. H. T., Balbo, L. C., Santia, G. W. D., Bracarense, A. P. F. R. L., Cunha, L. F. C. Fo.,.. Alfieri, A. A. (2018). Histophilus somni-associated syndromes in sheep from Southern Brazil. Brazilian Journal of Microbiology, 49(3), 591-600. doi: 10.1016/j.bjm.2017.12.008

Headley, S. A., Müller, M. C., Oliveira, T. E. S., Duarte, C. A. B. G., Pereira, P. F. V., Vieira, M. V.,... Pretto-Giordano, L. G. (2020). Diphtheric aspergillosis tracheitis with gastrointestinal dissemination secondary to viral infections in a dairy calf. Microbial Pathogenesis, 149(12), 104497. doi: 10.10 16/j.micpath.2020.104497

Headley, S. A., Oliveira, T. E. S., \& Cunha, C. W. (2020). A review of the epidemiological, clinical, and pathological aspects of malignant catarrhal fever in Brazil. Brazilian Journal of Microbiology, 51(3), 1405-1432. doi: 10.1007/s42770-020-00273-6

Headley, S. A., Oliveira, T. E. S., Li, H., Lisbôa, J. A. N., Queiroz, G. R., Fritzen, J. T. T., Flores, E. F., Alfieri, A. A., \& Cunha, C. W.
(2020). Immunohistochemical detection of intralesional antigens of ovine gammaherpesvirus-2 in cattle with sheepassociated malignant catarrhal fever. Journal of Comparative Pathology, 174(1), 86-98. doi: 10.1016/j.jcpa.2019.11.002

Hessman, B. E., Fulton, R. W., Sjeklocha, D. B., Murphy, T. A., Ridpath, J. F., \& Payton, M. E. (2009). Evaluation of economic effects and the health and performance of the general cattle population after exposure to cattle persistently infected with bovine viral diarrhea virus in a starter feedlot. American Journal of Veterinary Research, 70(1), 73-85. doi: 10.2460/ajvr.70.1.73

Hick, P. M., Read, A. J., Lugton, I., Busfield, F., Dawood, K. E., Gabor, L., Hornitzky, M., \& Kirkland, P. D. (2012). Coronavirus infection in intensively managed cattle with respiratory disease. Australian Veterinary Journal, 90(10), 381-386. doi: 10.1111/j.1751-0813.2012.00978.x

Hoppe, I., Souza-Pollo, A., Medeiros, A. S. R., Samara, S. I., \& Carvalho, A. A. B. (2019). HoBi-like pestivirus infection in an outbreak of bovine respiratory disease. Research in Veterinary Science, 126, 184191. doi: 10.1016/j.rvsc.2019.09.003

Ide, P. R., Thomson, R. G., \& Ditchfield, W. J. (1969). Experimental adenovirus infection in calves. Canadian Journal of Comparative Medicine, 33(1), 1-9. Retrieved from https://pubmed.ncbi.nlm. nih.gov/4304091

Jim, K. (2009). Impact of bovine respiratory disease (BRD) from the perspective of the Canadian beef producer. Animal Health Research Reviews, 10(2), 109-110. doi: $10.1017 / \mathrm{s} 1466252309990119$ 
Klima, C. L., Zaheer, R., Cook, S. R., Booker, C. W., Hendrick, S., Alexander, T. W., \& McAllister, T. A. (2014). Pathogens of bovine respiratory disease in North American feedlots conferring multidrug resistance via integrative conjugative elements. Journal of Clinical Microbiology, 52(2), 438. doi: 10. 1128/JCM.02485-13

Klima, C. L., Holman, D. B., Ralston, B. J., Stanford, K., Zaheer, R., Alexander, T. W., \& McAllister, T. A. (2019). Lower respiratory tract microbiome and resistome of bovine respiratory disease mortalities. Microbial Ecology, 78(2), 446-456. doi: 10.1007/s0 0248-019-01361-3

Lancaster, M. J., McGillivery, D. J., Patterson, R. M., \& Irwin, S. (1984). Pneumonia associated with Haemophilus somnus in a calf. Australian Veterinary Journal, 61(8), 269. doi: 10.1111/j.1751-0813.1984.tb15 545.x

Larsen, L., Tegtmeier, C., \& Pedersen, E. (2001). Bovine respiratory syncytial virus (BRSV) pneumonia in beef calf herds despite vaccination.Acta VeterinariaScandinavica, 42, 113-121, doi: 10.1186/1751-014742-113.

Leland, D. S., \& French, M. L. V. (1988). Virus Isolation and Identification. In E. $H$. Lennette, P. Halonen, F. A. Murphy, A. Balows, \& W. J. Hausler Jr. (Eds.), Laboratory diagnosis of infectious diseases principles and practice (pp. 3959). New York, NY: Springer.

Loneragan, G. H., Dargatz, D. A., Morley, P. S., \& Smith, M. A. (2001). Trends in mortality ratios among cattle in US feedlots. Journal of the American Veterinary Medical Association, 219(8), 1122-1127. doi: 10. 2460/javma.2001.219.1122.
López, A., \& Martinson, S. A. (2017). Respiratory system, mediastinum, and pleurae. In: J. F. Zachary (Ed.), Pathologic basis of veterinary disease (pp. 471-560). St. Louis, Missouri: Elsevier.

Luo, J., Ferguson, L., Smith, D. R., Woolums, A. R., Epperson, W. B., \& Wan, X. F. (2017). Serological evidence for high prevalence of Influenza D Viruses in Cattle, Nebraska, United States, 2003-2004. Virology, 501(1), 88-91. doi: 10.1016/j.virol.2016.11.004

Maes, R. K., Langohr, I. M., Wise, A. G., Smedley, R. C., Thaiwong, T., \& Kiupel, M. (2014). Beyond H\&E: integration of nucleic acidbased analyses into diagnostic pathology. Veterinary Pathology, 51(1), 238-256. doi: $10.1177 / 0300985813505878$

Magalhães, L. Q., Baptista, A. L., Fonseca, P. d. A., Menezes, G. L., Nogueira, G. M., Headley, S. A.,', Saut, J. P. E. (2017). Use of metaphylactic protocols based on the risk to develop bovine respiratory diseases in feedlot cattle. Ciência Rural, 47(8), e20161110. doi: 10.1590/0103-8478cr20 161110

Malafaia, P., Granato, T. A. L., Costa, R. M., Souza, V. C. d., Costa, D. F. A., \& Tokarnia, C. H. (2016). Major health problems and their economic impact on beef cattle under two different feedlot systems in Brazil. Pesquisa Veterinária Brasileira, 36(9), 837-843. doi: 10.1590/s0100-736x 2016000900008

Margineda, C. A., Zielinski, G. O., Jurado, S., Alejandra, F., Mozgovoj, M., Alcaraz, A. C., \& López, A. (2017). Mycoplasma bovis pneumonia in feedlot cattle and dairy calves in Argentina. Brazilian Journal of Veterinary Pathology, 10(2), 79-86. doi: 10.24070/bjvp.1983-0246.v10i2p79-86 
Marques, L. M., Buzinhani, M., Oliveira, R. C., Yamaguti, M., Ferreira, J. B., Neto, R. L., \& Timenetsky, J. (2007). Prevalence of mycoplasmas in the respiratory tracts of calves in Brazil. Veterinary Record, 161(20), 699-700. doi: 10.1136/vr.161.20.699

Martin, S. W., Bateman, K. G., Shewen, P. E., Rosendal, S., \& Bohac, J. E. (1989). The frequency, distribution and effects of antibodies, to seven putative respiratory pathogens, on respiratory disease and weight gain in feedlot calves in Ontario. Canadian Journal of Veterinary Research, 53(3), 355-362. Retrieved from https:// www.ncbi.nlm.nih.gov/pmc/articles/PMC 1255725/pdf/cjvetres00051-0103.pdf

Mattson, D. E., Norman, B. B., \& Dunbar, J. R. (1988). Bovine adenovirus type-3 infection in feedlot calves. American Journal of Veterinary Research, 49(1), 6769. Retrieved from https://pubmed.ncbi. nlm.nih.gov/2833138/

Maunsell, F. P., \& Donovan, G. A. (2009). Mycoplasma bovis infections in young calves. The Veterinary Clinics of North America. Food Animal Practice, 25(1), 139-177. doi: 10.1016/j.cvfa.2008.10.011

Mitra, N., Cernicchiaro, N., Torres, S., Li, F., \& Hause, B. M. (2016). Metagenomic characterization of the virome associated with bovine respiratory disease in feedlot cattle identified novelviruses and suggests an etiologic role for influenza $D$ virus. The Journal of General Virology, 97(8), 17711784. doi: 10.109 9/jgv.0.000492.

Moore, S. J., O'Dea, M. A., Perkins, N., \& O'Hara, A. J. (2015). Estimation of nasal shedding and seroprevalence of organisms known to be associated with bovine respiratory disease in Australian live export cattle. Journal of Veterinary Diagnostic Investigation, 27(1), 6-17. doi: 10.1177/1040638714559741

Murray, G. M., Cassidy, J. P., Clegg, T. A., Tratalos, J. A., McClure, J., O'Neill, R. G.,... S More, S. J. (2016). A retrospective epidemiological analysis of risk factors for a primary necropsy diagnosis of bovine respiratory disease. Preventive Veterinary Medicine, 132(9), 49-56. doi: 10.1016/j. prevetmed.20 16.08.009

Murray, G. M., More, S. J., Sammin, D., Casey, M. J., McElroy, M. C., O'Neill, R. G.,... Cassidy, J. P. (2017). Pathogens, patterns of pneumonia, and epidemiologic risk factors associated with respiratory disease in recently weaned cattle in Ireland. Journal of Veterinary Diagnostic Investigation, 29(1), 20-34. doi: 10.1177/1040638716674757

Muylkens, B., Thiry, J., Kirten, P., Schynts, F., \& Thiry, E. (2007). Bovine herpesvirus 1 infection and infectious bovine rhinotracheitis. Veterinary Research, 38(2), 181-209. doi: 10.1051/vetres:2006059

Ng, T. F., Kondov, N. O., Deng, X., Van Eenennaam, A., Neibergs, H. L., \& Delwart, E. (2015). A metagenomics and case-control study to identify viruses associated with bovine respiratory disease. Journal of Virology, 89(10), 5340-5349. doi: 10.1128/ jvi.00064-15

Nicholas, R. A. (2011). Bovine mycoplasmosis: silent and deadly. Veterinary Record, 168(17), 459-462. doi: 10.1136/vr.d2468

O'Toole, D., Allen, T., Hunter, R., \& Corbeil, L. B. (2009). Diagnostic exercise: myocarditis due to Histophilus somni in feedlot and backgrounded cattle. Veterinary Pathology, 46(5), 1015-1017. doi: 10.13 54/vp.08-VP-0332-O-DEX 
O'Toole, D., \& Sondgeroth, K. S. (2016). Histophilosis as a natural disease. In: R. Ahmed, Akira, S., Aktories, K., Casadevall, A., Compans, R. W., Galan, J. E., GarciaSastre, A., Malissen, B., Rappuoli, R. (Eds.), Current Topics in Microbiology and Immunology (pp. 15-48). Pennsylvania, PA: Springer.

Oliveira, T. E. S., Pelaquim, I. F., Flores, E. F., Massi, R. P., Valdiviezo, M. J. J., Pretto-Giordano, L. G.,... Headley, S. A. (2020). Mycoplasma bovis and viral agents associated with the development of bovine respiratory disease in adult dairy cows. Transboundary and Emerging Diseases, 67(Suppl 2), 8293. doi: 10.1111/tbed.13223

Oliveira, V. H. S., Dall Agnol, A. M., Fritzen, J. T. T., Lorenzetti, E., Alfieri, A. A., \& Alfieri, A. F. (2020). Microbial diversity involved in the etiology of a bovine respiratory disease outbreak in a dairy calf rearing unit. Comparative Immunology, Microbiology and Infectious Diseases, 71(8), 101494. doi: 10. 1016/j.cimid.2020.101494

Panciera, R. J., \& Confer, A. W. (2010). Pathogenesis and pathology of bovine pneumonia. The Veterinary Clinics of North America. Food Animal Practice, 26(2), 191214. doi: 10.1016/j.cvfa.2010.04.001

Pasqualotto, W., Sehnem, S., \& Winck, C. A. (2015). Incidência de rinotraqueíte infecciosa bovina (IBR), diarreia viral bovina $(B V D)$ e leptospirose em bovinos leiteiros da região Oeste de Santa Catarina - Brasil. Revista em Agronegócio e Meio Ambiente, 8(2), 249-270. Retrieved from https:// periodicos.unicesumar.edu.br/index.php/ rama/article/view/ 3034/2595

Philippou, S., Streckert, H. J., Otto, P., Reinhold, P., Elschner, M., Werchau, H., \& Morgenroth,
K. (1996). Morphological studies of the respiratory syncytial virus induced bronchiolitis in experimentally infected calves. Pathology, Research and Practice, 192(10), 1045-1056. doi: 10.1016/s03440338(96)80048-3

Pretto, G. L., Müller, E. E., Freitas, J. C., Mettifogo, E., Buzinhanr, M., \& Yamaguti, M. (2001). Isolamento de Mycoplasma bovis de bezerros com pneumonia. Veterinária Notícias, 7(1), 69-21.

Ramírez Romero, R., Chavarría Martínez, B., Nevárez Garza, A. M., Rodríguez Tovar, L. E., Dávila Martínez, C., Hernández Vidal, G., Hernández Escareño, J. J., \& López Mayagoitia, A. (2010). Demostración inmunohistoquímica de Mycoplasma bovis enlesionesneumónicascrónicasenganado en corral de engorda. Veterinaria México, 41(4), 289-296. Retrieved from: http:// www.scielo.org.mx/scielo.php?script=sci arttext\&pid=S0301-5092201000040 0005\&nrm=iso

Richter, V., Lebl, K., Baumgartner, W., Obritzhauser, W., Käsbohrer, A., \& Pinior, B. (2017). A systematic worldwide review of the direct monetary losses in cattle due to bovine viral diarrhoea virus infection. Veterinary Journal, 220(2), 80-87. doi: 10.1016/j.tvjl.2017.01.005

Risalde, M. A., Molina, V., Sonchez-Cordon, P. J., Pedrera, M., Romero-Palomo, F., Bautista, M. J., Moreno, A., \& GomezVillamandos, J. C. (2013). Comparison of pathological changes and viral antigen distribution in tissues of calves with and without preexisting bovine viral diarrhea virus infection following challenge with bovine herpesvirus-1. American Journal of Veterinary Research, 74(4), 598-610. doi: 10.2460/ajvr.74.4.598 
Rodriguez, F., Bryson, D. G., Ball, H. J., \& Forster, F. (1996). Pathological and immunohistochemical studies of natural and experimental Mycoplasma bovis pneumonia in calves. Journal of Comparative Pathology, 115(2), 151-162. doi: 10.1016/s0021-9975(96)80037-5

Sacco, R. E., McGill, J. L., Pillatzki, A. E., Palmer, M. V., \& Ackermann, M. R. (2014). Respiratory syncytial virus infection in cattle. Veterinary Pathology, 51(2), 427436. doi: 10.1177/03009858135013 41

Schibrowski, M. L., Gibson, J. S., Hay, K. E., Mahony, T. J., \& Barnes, T. S. (2018). Mycoplasma bovis and bovine respiratory disease: A risk factor study in Australian feeder cattle. Preventive Veterinary Medicine, 157(9), 152-161. doi: 10.1016/j. prevetmed.2018.06.005

Schneider, M. J., Tait, R. G., Jr., Busby, W. D., \& Reecy, J. M. (2009). An evaluation of bovine respiratory disease complex in feedlot cattle: Impact on performance and carcass traits using treatment records and lung lesion scores. Journal of Animal Science, 87(5), 1821-1827. doi: 10.2527/ jas.2008-1283

Snowder, G. D., Van Vleck, L. D., Cundiff, L. V., \& Bennett, G. L. (2006). Bovine respiratory disease in feedlot cattle: environmental, genetic, and economic factors. Journal of Animal Science, 84(8), 1999-2008. doi: 10.2527/jas.2006-046

Taylor, J. D., Fulton, R. W., Lehenbauer, T. W., Step, D. L., \& Confer, A. W. (2010). The epidemiology of bovine respiratory disease: What is the evidence for predisposing factors? Canadian Veterinary Journal, 51(10), 1095-1102.
Timsit, E., Hallewell, J., Booker, C., Tison, N., Amat, S., \& Alexander, T. W. (2017). Prevalenceand antimicrobial susceptibility of Mannheimia haemolytica, Pasteurella multocida, and Histophilus somni isolated from the lower respiratory tract of healthy feedlot cattle and those diagnosed with bovine respiratory disease. Veterinary Microbiology, 208(9), 118-125. doi: 10.10 16/j.vetmic.2017.07.013

Tortorelli, G., Carrillo Gaeta, N., Mendonça Ribeiro, B. L., Miranda Marques, L., Timenetsky, J., \& Gregory, L. (2017). Evaluation of Mollicutes microorganisms in respiratory disease of cattle and their relationship to clinical signs. Journal of Veterinary Internal Medicine, 31(4), 12151220. doi: 10.1111/ jvim.14721.

Tucker, C. B., Coetzee, J. F., Stookey, J. M., Thomson, D. U., Grandin, T., \& Schwartzkopf-Genswein, K. S. (2015). Beef cattle welfare in the USA: identification of priorities for future research. Animal Health Research Reviews, 16(2), 107-124. doi: $10.1017 / s 1466252315000171$

Tuncer, P., \& Yeşilbağ, K. (2015). Serological detection of infection dynamics for respiratory viruses among dairy calves. Veterinary Microbiology, 180(3-4), 180185. doi: 10.1016/j.vetmic.2015.08.025

Urban-Chmiel, R., \& Grooms, D. L. (2012). Prevention and control of bovine respiratory disease. Journal of Livestock Science, 3(1), 27-36. Retrieved from https://livestockscience.in/wp-content/ uploads/2012/Bovine_Respiratory_ Disease. pdf 
USDA. Death loss in U.S. cattle and calves due to predator and nonpredator causes, 2015. Centre Avenue : Animal and Plant Health Inspection Service (APHIS), Veterinary Services (VS), National Animal Health Monitoring System (NAHMS), United States Department of Agriculture, 2017. 77 p. Retrieved from https://www.aphis. usda.gov/animal_health/nahms/general/ downloads/cattle_calves_deathloss_ 2015.pdf

Vaucher, R. d. A., Dezen, D., Simonetti, A. B., Spilki, F. R., \& Roehe, P. M. (2011). Phylogenetic characterization of bovine parainfluenza 3 from contaminated cell cultures and field isolates from Brazil. Brazilian Journal of Microbiology, 42(4), 1440-1444. doi: 10.1590/S1517-83822011000400029

Warren, L. M., Babiuk, L. A., \& Campos, M. (1996). Effects of BHV-1 on PMN adhesion to bovine lung endothelial cells. Veterinary Immunology and Immunopathology, 55(1-3), 73-82. doi: 10.1016/s0165-2427 (96)05630-9
Wilson, B. K., Step, D. L., Maxwell, C. L., Wagner, J. J., Richards, C. J., \& Krehbiel, C. R. (2015). Evaluation of multiple ancillary therapies used in combination with an antimicrobial in newly received high-risk calves treated for bovine respiratory disease. Journal of Animal Science, 93(7), 3661-3674. doi: 10.2527/jas.2015-9023

Yarnall, M. J., \& Thrusfield, M. V. (2017). Engaging veterinarians and farmers in eradicating bovine viral diarrhoea: a systematic review of economic impact. The Veterinary Record, 181(13), 347. doi: $10.1136 /$ vr.104370.

Zhang, M., Hill, J. E., Godson, D. L., Ngeleka, M., Fernando, C., \& Huang, Y. (2020). The pulmonary virome, bacteriological and histopathological findings in bovine respiratory disease from western Canada. Transbound Emerg Dis, 67(2), 924-934. doi: 10.1111/tbed.13419 
